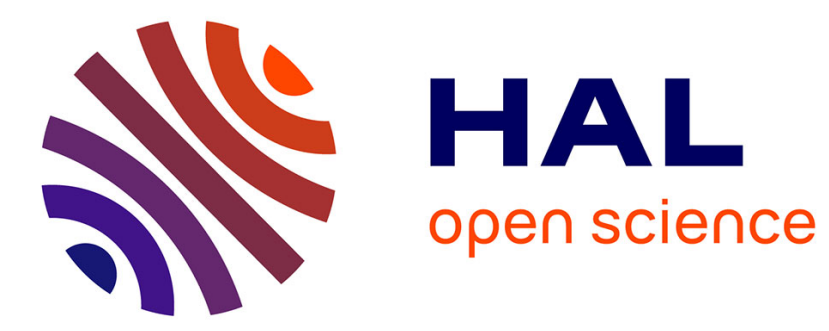

\title{
Do benthic invertebrates use hyporheic refuges during streambed drying? A manipulative field experiment in nested hyporheic flowpaths
}

Chafik Maazouzi, D. Galassi, C. Claret, Bernard Cellot, F. Fiers, Dominique Martin, Pierre Marmonier, Marie-José Dole-Olivier

\section{To cite this version:}

Chafik Maazouzi, D. Galassi, C. Claret, Bernard Cellot, F. Fiers, et al.. Do benthic invertebrates use hyporheic refuges during streambed drying? A manipulative field experiment in nested hyporheic flowpaths. Ecohydrology, 2017, 10 (6), pp.e1865. 10.1002/eco.1865 . hal-01681639

\section{HAL Id: hal-01681639 \\ https://hal.science/hal-01681639}

Submitted on 11 Jun 2018

HAL is a multi-disciplinary open access archive for the deposit and dissemination of scientific research documents, whether they are published or not. The documents may come from teaching and research institutions in France or abroad, or from public or private research centers.
L'archive ouverte pluridisciplinaire HAL, est destinée au dépôt et à la diffusion de documents scientifiques de niveau recherche, publiés ou non, émanant des établissements d'enseignement et de recherche français ou étrangers, des laboratoires publics ou privés. 


\title{
Do benthic invertebrates use hyporheic refuges during streambed drying? A manipulative field experiment in nested hyporheic flowpaths
}

\author{
C. Maazouzi ${ }^{1}$ | D. Galassi ${ }^{4}$ | C. Claret $^{2}$ | B. Cellot $^{1}$ | F. Fiers ${ }^{3}$ | D. Martin ${ }^{1}$ | P. Marmonier ${ }^{1}$ । \\ M.-J. Dole-Olivier ${ }^{1}$
}

${ }^{1}$ University of Lyon, University Claude Bernard Lyon 1, UMR-CNRS 5023 LEHNA, 43 Boulevard du 11 Novembre 1918, 69622 Villeurbanne Cedex, France

${ }^{2}$ IMBE, Institut Méditerranéen de Biodiversité et Ecologie marine et continentale, UMR CNRS 7263-Aix Marseille University, Avignon University, CNRS, IRD, IMBE, Marseille, France

${ }^{3}$ Invertebrate Section, Royal Belgian Institute of Natural Sciences, Vautierstraat, 29, B-1000 Brussels, Belgium

${ }^{4}$ Department of Life, Health and Environmental Sciences, University of L'Aquila, Via Vetoio, Coppito, I-67100 L'Aquila, Italy

Correspondence

M-J. Dole-Olivier, University of Lyon, University Claude Bernard Lyon 1, UMR-CNRS 5023 LEHNA, 43 Boulevard du 11 Novembre 1918, 69622 Villeurbanne Cedex, France. Email: marie-jose.olivier@univ-lyon1.fr

Funding information

InBioProcess project, Grant/Award Number: ANR-06-BDIV-007-InBioProcess 2007-2010

\begin{abstract}
The existence of resilience mechanisms related to a disturbance, such as invertebrate migrations into the hyporheic zone ( $\mathrm{HZ}$, saturated subsurface interstices), promotes persistence of benthic communities in river ecosystems. Water exchanges through the $\mathrm{HZ}$, which influence the distribution of biota, are heterogeneous at different scales, determining nested hyporheic flowpaths. The effect of these nested exchanges on the use of the hyporheic refuges by benthic invertebrates is still unknown. We simulated streambed drying in a stream section where hydrological exchanges were considered at riffle (upstream or downstream of riffles) and floodplain (downstream end of a floodplain) scales. Physicochemical indicators determined that local hyporheic flowpaths (up- and downwelling zones) were nested in a large-scale downwelling section of the river. In this situation, the effect of $24 \mathrm{~h}$ of experimental drying on the distribution of invertebrates was examined at three sediment depths to follow their migrations into the $\mathrm{HZ}$. Whereas invertebrate assemblages did not change in the control channel, abundance of benthic invertebrate increased in the $\mathrm{HZ}$ of the impact channel (up to seven-fold). Changes occurred rapidly (15-24 h) and only upstream of riffle where surface water down-welled. The migration was taxon-specific and concerned the most abundant benthic taxa that temporarily colonize the HZ ("temporary hyporheos," e.g., Leuctra cf. fusca, Baetis sp., Caenis sp., Orthocladiinae, Tanypodinae). In the context of climate change, hyporheic refuge use will promote persistence of communities facing the increasing frequency of extreme hydrological events. Improved knowledge about the distribution and function of these refuges is becoming crucial for river managers.
\end{abstract}

\section{KEYWORDS}

geomorphology, hyporheic exchanges, invertebrates, nested flowpaths, refuge, streambed drying

\section{1 | INTRODUCTION}

Changes in land use, climate change, and water resource use interact to induce physical and hydrological modifications in rivers and streams (Rolls, Leigh, \& Sheldon, 2012). Flow regimes are especially affected with more extended low flows and higher frequencies of extreme events, such as floods and droughts (Dai, 2011; Lehner, Döll, Alcamo, Henrichs, \& Kaspar, 2006). During severe events, threats to the aquatic environment are likely to increase, with resistance and resilience becoming crucial properties of communities. Resilience, that is, the return time to a stable state following a perturbation (Gunderson, 2000), may be enhanced by the use of in-stream refuges by benthic invertebrates (Lake, 2003). Refuges are places where the negative effects of disturbance are weaker than in the surrounding area (Lancaster \& Belyea, 1997). Refuges that facilitate post-drying resilience include the use of microhabitats available in the streambed (Stubbington, 2012) or within the alluvia. In permeable streambeds, the hyporheic zone $(\mathrm{HZ})$ may offer preferable living conditions for invertebrates during hydrological disturbance (Angelier, 1953; Dole-Olivier \& Marmonier, 1992a; Marmonier \& Dole, 1986). The hyporheic refuge hypothesis (HRH, Palmer, Bely, \& Berg, 1992) proposes that benthic invertebrates increase their survival of adverse conditions in the surface stream by moving into the $\mathrm{HZ}$ (Stubbington, 2012). Nevertheless, this idea has long been contentious, in part due 
to differing interpretations of what constitutes refuge use (Stubbington, 2012) and in part due to the strong heterogeneity of the hyporheic habitat (Brunke \& Gonser, 1997; Malard, Tockner, Dole-Olivier, \& Ward, 2002; Rouch, 1995), which results in a patchy distribution of interstitial refuges (Dole-Olivier, Marmonier, \& Beffy, 1997; Marmonier \& Creuzé des Châtelliers, 1991).

Patchiness of the $\mathrm{HZ}$ is caused by (a) sediment characteristics, including porosity, permeability, grain size distribution, interstitial architecture, and the thickness of alluvia and their degree of stability; and (b) interstitial water quality, including oxygenation, temperature, and food resources (Datry, Malard, \& Gibert, 2005). In natural conditions, these interacting factors are predominantly governed by geomorphology and hydrology, which determine, at different spatial scales, patterns of hyporheic exchanges between surface and ground waters (Dole-Olivier \& Marmonier, 1992b; Malard, Ward, \& Robinson, 2000; Tonina \& Buffington, 2007; Woessner, 2000). Therefore, issues related to the $\mathrm{HRH}$ could be studied in such environmental patchiness by investigating how hyporheic alluvia act as a refuge in various hydrogeomorphological situations (e.g., local-scale hyporheic flowpaths nested in a large-scale upwelling or in a large-scale downwelling, Dole-Olivier et al., 1997; Stubbington, Wood, Reid, \& Gunn, 2011). This hydrological perspective was presented by Dole-Olivier (2011) who proposed several hypotheses along constrained and unconstrained river reaches.

The optimal hyporheic refuge should occur under environmental conditions suitable for life in the interstices, such as alluvial accumulations sufficiently thick to allow deep colonization by invertebrates (i.e., at least 0.4-0.7 m, Bretschko, 1992), high sediment permeability, permanent saturation, high levels of dissolved oxygen (DO), and moderate temperatures (Boulton, Datry, Kasahara, Mutz, \& Stanford, 2010; Strayer, May, Nielsen, Wollheim, \& Hausam, 1997). Such conditions are observed when deep phreatic water mixes with subsurface water flows, that is, when local hyporheic flowpaths are nested within a major upwelling section (Dole-Olivier, 2011). Acceptable refuge conditions may also be found in major downwelling sections as long as the accumulation of alluvia and sediment permeability are high, and the hyporheic interstices are filled with water.

This study was conducted at the end of an alluvial floodplain where the constriction of the valley typically generates large-scale hydrological exchanges (Baxter \& Hauer, 2000). In this river section, we selected side channels containing riffles predicted to induce localscale up- and downwelling zones (Buffington \& Tonina, 2009). In this situation of nested hyporheic flowpaths (Baxter \& Hauer, 2000), we created an artificial streambed drying by damming one side channel of the river (impact channel) to examine the vertical migration of benthic invertebrates into the $\mathrm{HZ}$ during the experimental disturbance. The results were compared with a nearby channel that was not impacted by streambed drying (control channel). After the demonstration of the presence of a major downwelling (Appendix A), we hypothesized that drying would alter local hyporheic flowpaths in the impact channel, decreasing surface water infiltration and promoting interstitial water flow (i.e., increases in specific conductance and nitrate concentration; decrease in DO), and we predicted no changes in the control channel (prediction 1).
The main part of this work measured the effect of streambed drying on the vertical distribution of invertebrates in the $\mathrm{HZ}$. The impact channel and the control channel were predicted to differ, with no temporal change in the control channel and a significant increase in benthic invertebrate abundance in the $\mathrm{HZ}$ measured by differences before (one time) and during (three times) drying (prediction 2).

In this context of major downwelling, the accumulation of benthic fauna was predicted to be higher in local downwelling than in local upwelling zones (prediction 3) due to harsher environmental conditions in surface areas, where water was completely absent.

\section{2 | MATERIALS \& METHODS}

\section{1 | Study area}

The experiment was conducted in the Drôme River (France), a tributary of the Rhône River located in the eastern side of the Rhône basin. The study site $(X=4.946852, Y=44.2992, Z=148)$ was situated $10 \mathrm{~km}$ from the confluence with the Rhône River, in the downstream part of a braided section flowing over a large floodplain (length > $3 \mathrm{~km}$ ) within a nature reserve (Réserve Naturelle des Ramières du Val de Drôme, Figure 1a). This section was bounded downstream by a constrained river reach (length $>4 \mathrm{~km}$ ), in which an embankment confined the natural floodplain (maximum width $\sim 350 \mathrm{~m}$ ) to an 80-m wide band. The stream valley had thick accumulations of sedimentary material (8 to $10 \mathrm{~m}$, SOGREHA, 1991) promoting the development of a deep $\mathrm{HZ}$. The riverbed was highly unstable, comprising cobbles, pebbles, and granules with very coarse sands (Wentworth, 1922). The hydraulic conductivity of the alluvia was generally high (average $4.10^{-3} \mathrm{~m} / \mathrm{s}$, SOGREHA, 1991). Local data on permeability collected during the present study (measured by the infiltration time $t$ of $1 \mathrm{~L}$ of water in the piezometer) indicated no noticeable differences between any of the sampling points and very high permeability everywhere $(t<<1 \mathrm{~s})$. In this section, the mean annual discharge of the stream was $17.7 \mathrm{~m}^{3} / \mathrm{s}$. Experiments were performed during a low-water period (26-27 June 2009, discharge $=4 \mathrm{~m}^{3} / \mathrm{s}$ ) after more than 1 month with a low discharge $<25 \mathrm{~m}^{3} / \mathrm{s}$.

\subsection{Artificial flow manipulation}

A small, braided "impact" channel ( $\approx 9-\mathrm{m}$ width) was dammed to simulate a natural drying by building a temporary barrier of 1-mm thick plastic sheeting supported by a fence of wire placed across the impact channel (Boulton, Harvey, \& Proctor, 2004). The channel was adjacent to a larger control channel $(\approx 31-\mathrm{m}$ width), which received the diverted water (Figure 1b). Water flow in the control channel was not significantly affected by the impact channel diversion because its width and its discharge were much higher than those of the side channel ( $3.574 \mathrm{~m}^{3} / \mathrm{s}$ versus $0.316 \mathrm{~m}^{3} / \mathrm{s}$, respectively). The dam immediately stopped the water flow in the channel and retained the same amount of flow diversion for the duration of the experiment. Following surface drying, water flow through the gravels maintained a weak discharge at the centre of the channel. Nevertheless, all sampling points were positioned close to the banks and were effectively submitted to drying. At most sampling points sediment interstices remained saturated with 
FIGURE 1 Study area. (a) The river floodplain, limited at its downstream part by a channelized reach. (b) Study site, impact and control channels, and summary of the sampling design. T1 to T4: Sampling times

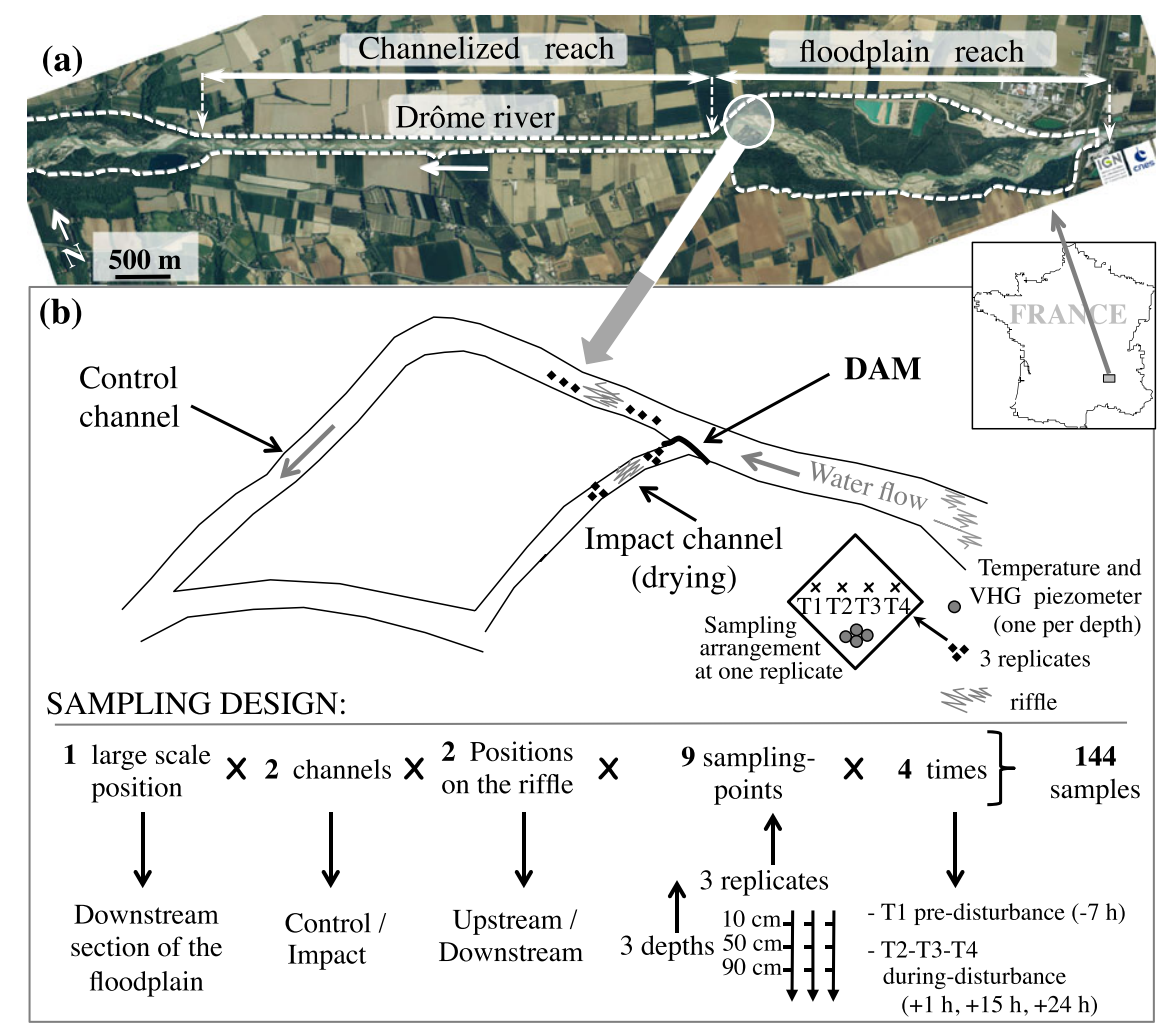

water, especially at the downstream position, even if the uppermost layer of the sediments dried at the upstream position. Nevertheless, the extension of this drying into the $\mathrm{HZ}$ did not exceed $10 \mathrm{~cm}$ in depth.

The drying was intentionally very rapid to mimic natural disconnections of lateral channels during summer (Malard, Tockner, \& Ward, 1999) when the total discharge of such braided streams is very low (i.e., $<4 \mathrm{~m}^{3} / \mathrm{s}$ during the sampling period), a slight decrease in discharge (e.g., $1 \mathrm{~m}^{3} / \mathrm{s}$ ) produces abrupt disconnections of side channels, which are typically situated at a higher altitude than the main channel (Poole, Stanford, Running, \& Frissel, 2006).

Samples of water and fauna were collected $7 \mathrm{~h}$ before flow diversion (10:45, time T1) and $1 \mathrm{~h}$ (18:45, time T2), $15 \mathrm{~h}$ (08:45, time T3), and $24 \mathrm{~h}$ (17:45, time T4) after diversion (Figure 1b). The rapid reduction in surface flow within the lateral channels informed the duration of the experiment because under natural conditions, invertebrates would have to migrate rapidly to avoid substrate drying after channel disconnection. Nevertheless, this duration, such as the short time between sampling periods (several hours), was in accordance with the possible rapid movements of the fauna, as reported in other sampling designs (Gayraud, Philippe, \& Maridet, 2000; Holomuzki \& Biggs, 2000; Palmer et al., 1992; Sherman \& Coull, 1980; Stubbington, Hoggan, \& Wood, 2017; Vadher, Stubbington, \& Wood, 2015).

\section{3 | Sampling design}

One riffle was selected in the impact channel and another in the control channel; the riffle in the impact channel was situated $<10 \mathrm{~m}$ downstream to the dam. As local upwellings and downwellings typically occur at the riffle scale (White, 1993), upstream and downstream positions were selected within each riffle $(\approx 15 \mathrm{~m}$ from each other, Figure 1b), with three replicate sampling points located within each position (Boulton, Harvey, et al., 2004; Malard, Ferreira, Dolédec, \& Ward, 2003). A minimum distance of $>2 \mathrm{~m}$ between each replicate was considered adequate to avoid sampling interactions (Boulton, Dole-Olivier, \& Marmonier, 2003). To determine the vertical distribution of the fauna at each sampling point from T1 to T4, samples were obtained at three depths below the sediment surface: $10 \mathrm{~cm}$ (top layer, D1), $50 \mathrm{~cm}$ (shallow, D2), and $90 \mathrm{~cm}$ (deep, D3). The sampling design is summarized in Figure $1 \mathrm{~b}$.

\section{4 | Instrumentation and sampling}

Invertebrate samples were collected using Bou-Rouch sampling equipment (Bou \& Rouch, 1967). At each sampling point, a perforated metal pipe $20 \mathrm{~mm}$ in internal diameter (nine rows of four 5-mm-diameter holes in a 13-cm band, starting $4 \mathrm{~cm}$ from the distal end of the pipe) was driven into the sediment successively to each depth (three samples from one insertion point, from D1 to D2 and D3). Invertebrates were collected from each depth using a manual pump primed with $250 \mathrm{ml}$ of filtered water. Five litres (i.e., a Bou-Rouch sample volume used in other studies: Malard et al., 2003; Boulton, Dole-Olivier, \& Marmonier, 2004; Capderrey, Datry, Claret, \& Malard, 2013) of water, sediment, and organic matter were pumped, washed, elutriated, and filtered through a $200-\mu \mathrm{m}$ mesh net, to retain invertebrates, including meiofauna but excluding a few small-sized groups, such as rotifers, tardigrades, and the nauplii of copepod crustaceans. Samples were preserved in the field in a $>70 \%$ alcohol solution mixed with eosin to stain the invertebrates.

Water temperature and specific conductance were measured in the sampled water using a thermo-conductimeter (LF92, WTWTM, Weilheim, Germany). Data loggers (VEMCO Minilog-II-T, VEMCO, Bedford, New Scotland, Canada) were installed in different perforated 
pipes driven into the sediment to depths D1, D2, D3, and also D4, $-130 \mathrm{~cm}$ below the surface, at each position in each riffle to record changes in thermal patterns during the experiment at 5-minute intervals. DO concentrations were measured using a portable oximeter (WTW OXI 330 meter, Weilheim, Germany), in $1 \mathrm{~L}$ of water collected with a peristaltic pump, to prevent artificial oxygenation during sample collection. A subsample was filtered through a Whatman GF/C glass fibre filter and was transported to the laboratory for analysis of nitrate and chloride concentrations using standard colourimetric methods (Grashoff, Ehrhardt, \& Kremling, 1983).

The vertical hydraulic gradient (VHG) estimates the direction and potential strength of hydrological exchange between surface water and hyporheic water. Permanent mini-piezometers (1.7-mm diameter) were driven into the sediments to D1, D2, and D3 using a T-bar, to evaluate the VHG at each position, depth, and time. Measurements were collected by comparing the surface water level in the stream and the groundwater level in the piezometers using a piezometric probe. The surface water level was measured using a transparent stilling tube for stabilization during measurement (Baxter, Hauer, \& Woessner, 2003). To allow comparisons across depths, values were transformed according to Dahm and Valett (1996):

$$
\text { VHG }=\left(h_{s}-h_{p}\right) / L,
$$

where $h_{s}$ represents the height of the top of the piezometer above the stream surface (expressed in $\mathrm{cm}$ ), $h_{p}$ is the height from the top of the piezometer to the water in the piezometer $(\mathrm{cm})$, and $\mathrm{L}$ is the depth of the piezometer in the sediments $(\mathrm{cm})$. The resulting unitless ratio is positive in upwellings and negative in downwellings.

One day before the experiment began, pipes for temperature loggers and VHG piezometers were inserted into the substrate, and the dam was preconstructed (except the plastic film). Each point (replicate or time) was positioned and identified by a rod to avoid repeated sampling at the same point and to avoid disturbing the sampling points by trampling. At each time, sampling was conducted concomitantly by three experimenters per position (12 experimenters); the 36 samples ( 2 channels $\times 2$ positions $\times 3$ replicates $\times 3$ depths) were collected during a 15 - to 20-minute period (Figure 1b).

Nine of the 144 planned samples were not obtained; all were from the impact channel. Specifically, two replicate points were clogged at D3 (T3, at the upstream position), and seven were dry at D1 during experiment (T3, one replicate at the upstream position and two at the downstream position; T4, two replicates at both upstream and downstream positions).

\section{5 | Sample processing}

Invertebrate samples were sorted in the laboratory under a stereomicroscope $(\times 20)$. Taxonomic resolution was to the species level for most crustaceans (Cladocera, Ostracoda, Copepoda, Isopoda, and Amphipoda) and as far as practical for the insects (family, genus, or species level). Other groups (Turbellaria, Nematoda, Oligochaeta, Bivalvia, Gastropoda, and Hydracarina) were not identified further. Taxa were classified according to the four ecological categories (stygoxene, temporary hyporheos $(\mathrm{TH})$, permanent hyporheos, and stygobiont) proposed by Gibert, Stanford, Dole-Olivier, and Ward (1994) to analyse hyporheic communities. Stygoxenes and the TH are invertebrates associated with the benthic habitat. Although the presence of stygoxenes species is accidental in the $\mathrm{HZ}, \mathrm{TH}$ species are more regular residents; however, they cannot spend their complete life cycle in the $\mathrm{HZ}$. Permanent hyporheos $(\mathrm{PH})$ may spend their entire life in groundwater habitats or in surface water, whereas stygobionts (SB) are obligate groundwater dwellers.

\section{6 | Statistical analyses}

A direct representation of temporal variation in temperature at each channel-position-depth (records from data loggers) was used to inform a preliminary description of nested hyporheic flowpaths. A multi-parametric approach based on a principal component analysis was used for the other physicochemical parameters (specific conductance, chloride and nitrate concentrations, DO, and VHG) to reduce the dimensionality of the dataset and identify the factors accounting for most of the total variance, allowing the detection of spatial and temporal hydrological patterns in each channel. For each channel or position, sample centroids (three replicates) were plotted in twodimensional ordination space to reveal temporal trajectories of changes in water characteristics at each depth (Appendix A, prediction 1). A multivariate analysis of variance was used on these variables to test the statistical significance of spatial patterns (channel and position) and to determine the effect of drying (time) on the hyporheic flowpaths (prediction 1).

After applying a square root transformation of data followed by a Wisconsin double standardization, faunal data were ordinated with nonmetric multidimensional scaling (NMDS), generating a twodimensional ordination. As for physicochemical variables, at each channel or position, sample centroids (three replicates) were plotted in two-dimensional ordination space to reveal temporal trajectories of changes in assemblage composition at each depth (predictions 2-3). A permutational multivariate analysis of variance was used to compare invertebrate assemblage compositions between channels, positions, depths, and times (predictions 2-3). All statistical analyses were conducted with R (R Development Core Team, 2011) using the ade4 (Dray \& Dufour, 2007), vegan (Oksanen et al., 2012), and MASS (Venables \& Ripley, 2002) libraries.

\section{7 | Nested hyporheic flowpaths}

In the control channel, temperature patterns indicated surface water infiltration at both positions with more pronounced infiltration downstream, whereas in the impact channel, they reflected a downwelling of surface water at the upstream position and a weak upwelling at the downstream position (Figure 2a,b, comments in Appendix A). Generally, the low amplitude of spatial variation in water temperature along with minima close to $18{ }^{\circ} \mathrm{C}$ (i.e., rather high values) indicated no connections with deep phreatic waters, which are typically much cooler in this area $\left(12.6 \pm 0.9{ }^{\circ} \mathrm{C}\right.$, Dole-Olivier, unpublished data) indicating for the absence of large-scale upwelling. Specific conductance, DO, nitrate, VHG, and Chloride values corroborated these observations. As local-scale patterns were comparable and the values 


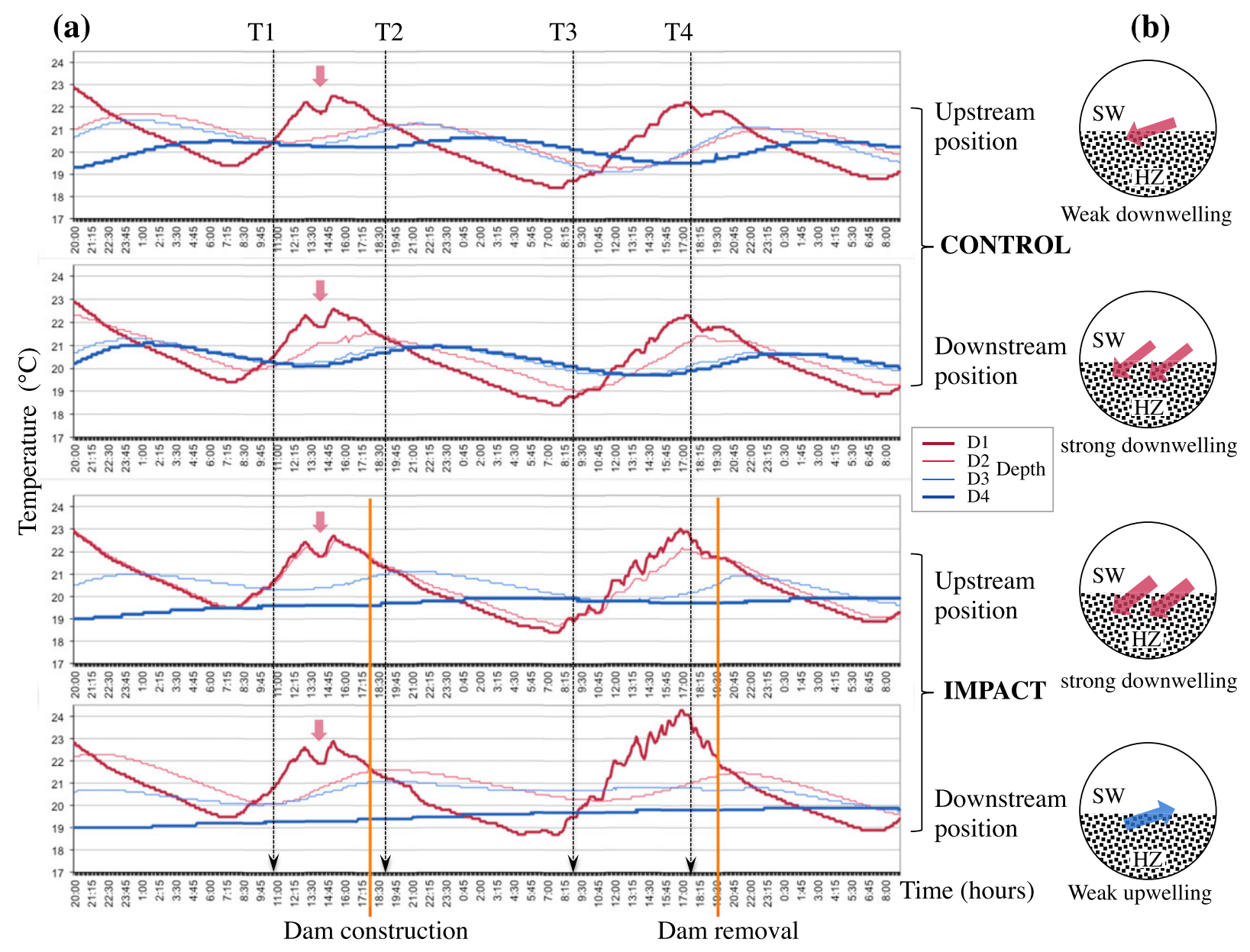

FIGURE 2 (a) Temperature records (every 5 minutes, from June 25 to 27, 2009) in the control and impact channels at upstream and downstream riffle positions and at four depths ( $D 1=10 \mathrm{~cm}, \mathrm{D} 2=30 \mathrm{~cm}, \mathrm{D} 3=90 \mathrm{~cm}$, and D4 $=130 \mathrm{~cm}$ ) below the surface of the sediment. Dotted vertical lines indicate the sampling times (T1 to T4); coloured vertical lines in the impact channel indicate dam construction and dam removal. The coloured arrow indicates an example of daily solar variation. (b) Hydrological patterns inferred from physicochemical data (SW, surface water; HZ, hyporheic zone). One arrow indicates shallow exchanges; two arrows indicate deeper exchanges of water

of the physicochemical indicators measured in the $\mathrm{HZ}$ were close to those in the surface stream, we conclude that local hyporheic flowpaths were nested in a large-scale downwelling. A full description of these flowpaths is provided in Appendix A (Figures 2, 3, Tables 1, 2).

\section{3 | RESULTS}

\section{1 | Temporal variation of hyporheic flowpaths}

Before dam construction, the temporal changes in temperature due to solar variation were similar at D1 across channels and positions (see arrows in Figure 2a). After dam construction, greater temporal variability was observed in the impact channel during daylight hours (08:00-19:00) compared to the control. This higher variability was observed at both D1 and D2 at the upstream riffle position, and it was detectable only at $\mathrm{D} 1$ at the downstream position despite a difference on maximal values $\left(24.3^{\circ} \mathrm{C}\right.$ downstream versus $23^{\circ} \mathrm{C}$ upstream).

Specific conductance, DO, nitrate, VHG, and Chloride also revealed a temporal effect related to drying (MANOVA, Table 1). Significant interactions indicated that the temporal change differed between channels, positions, and depths (Table 1). Principal components 1-3 of principal component analysis explained $70.61 \%$ of the total variance (Figure 3b). The PC1 axis (28.67\%) was related to specific conductance, nitrate concentration (positive scores), and DO (negative scores), and the PC2 axis (21.08\%) was related to nitrate concentration (positive scores) and specific conductance (negative scores, Figure 3a). The PC3 axis (20.85\%) was mainly correlated with VHG and chloride content (positive scores). The ordination of samples along the PC1-PC2 factorial plane showed gradual temporal changes in the impact channel (Figure 3f), mostly in relation to increasing values of nitrate and decreasing DO (Figure 3a). These temporal changes in the impact channel differed across depths (Table 1). Temporal trajectories of changes in water characteristics overlapped among depths and positions (Figure 3h), except between D1 and D2 at the upstream position, and between upstream and downstream positions at D1. Temporal changes at D1 in the upstream position were pronounced and overlapped only slightly with all the other trajectories (Figure 3h). These changes were related to increases in specific conductance and/or DO. Conversely, in the control channel, there was no gradual change from T1 to T4 (Figure 3d). Temporal trajectories of changes in water characteristics overlapped considerably among positions and depths (Figure 3g), indicating no clear temporal changes in this channel. 


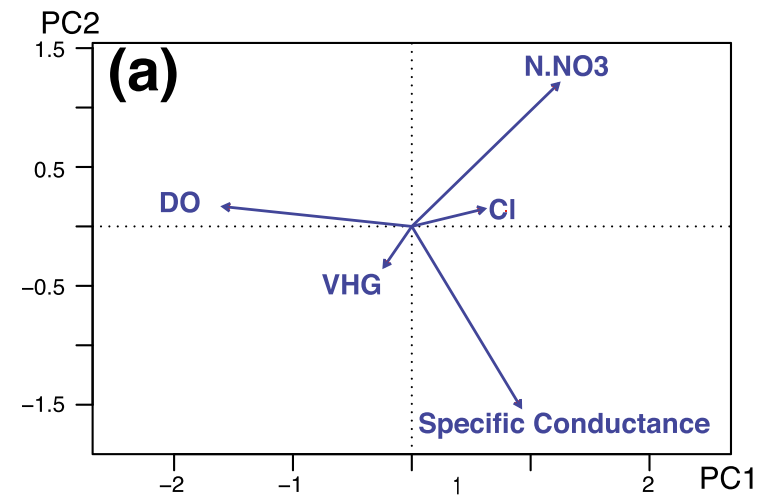

\section{(b)}

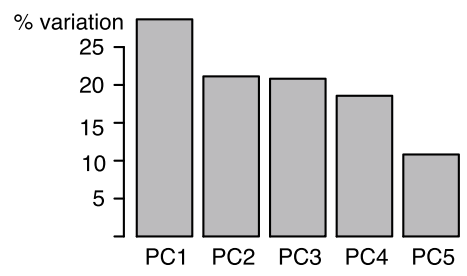

CONTROL channel
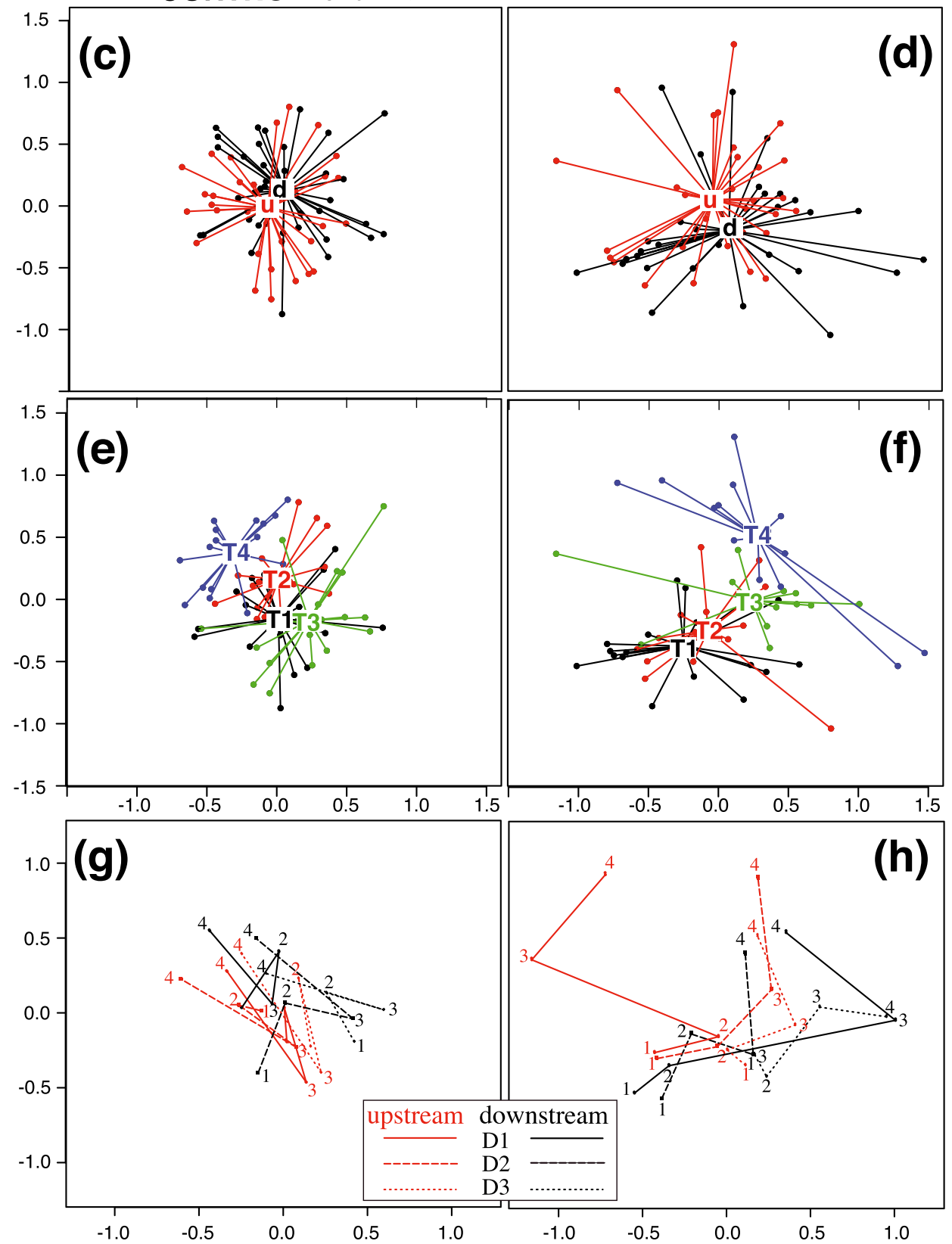

FIGURE 3 Principal component analysis. (a) Correlation circle of the five parameters on the PC1-PC2 factorial plane. (b) Percentage of the total variance explained by the first five axes. Ordination of samples on the PC1-PC2 factorial plane for the control (c-e) and impact (d-f) channels. Samples refer to upstream ( $u$ ) or downstream (d) positions ( $c \& d$ ) and to sampling times (T1 to T4, e \& f). Two-dimensional plot of sample centroids (three replicates) revealing the temporal trajectories of changes in water characteristics at the three depths (D1, D2, and D3) and at the two positions in the control (g) and impact (h) channels. Continuous, dashed and dotted lines corresponds to D1, D2, and D3, respectively. Numbers 1 to 4 correspond to times T1 to T4 
TABLE 1 Results of the multivariate analysis of variance processed on the five physicochemical parameters (specific conductance, VHG, DO, chloride, and $\mathrm{N}-\mathrm{NO}_{3}$ contents) to test the influences of channel, position, time, and depth as well as their interactions

\begin{tabular}{lrcrc} 
& df & $\begin{array}{c}\text { Pillai's } \\
\text { trace }\end{array}$ & F & $p$ value \\
\hline Channel (control vs. impact) & 1 & 0.081 & 1.408 & .230 \\
\hline Position (upstream vs. downstream) & 1 & 0.603 & 24.314 & $<.001^{* * *}$ \\
\hline Depth (D1, D2, D3) & 2 & 0.647 & 7.747 & $<.001^{* * *}$ \\
\hline Time (T1, T2, T3, T4) & 3 & 1.127 & 9.865 & $<.001^{* * *}$ \\
\hline Channel $\times$ position & 1 & 0.184 & 3.603 & $<.01^{* *}$ \\
\hline Channel $\times$ depth & 2 & 0.186 & 1.662 & .09 \\
\hline Position $\times$ depth & 2 & 0.466 & 4.924 & $<.001^{* * *}$ \\
\hline Channel $\times$ time & 3 & 0.74 & 5.369 & $<.001^{* * *}$ \\
\hline Position $\times$ time & 3 & 0.232 & 1.372 & .161 \\
\hline Depth $\times$ time & 6 & 0.433 & 1.329 & .118 \\
\hline Channel $\times$ position $\times$ depth & 2 & 0.267 & 2.498 & $<.01^{* *}$ \\
\hline Channel $\times$ position $\times$ time & 3 & 0.336 & 2.067 & $.012^{*}$ \\
\hline Channel $\times$ depth $\times$ time & 6 & 0.375 & 1.134 & .289 \\
\hline Position $\times$ depth $\times$ time & 6 & 0.317 & 0.948 & .548 \\
\hline Channel $\times$ Position $\times$ depth $\times$ time & 6 & 0.579 & 1.837 & $<.01^{* *}$ \\
\hline Residuals & 84 & & & \\
\hline
\end{tabular}

Note. $\mathrm{DO}=$ dissolved oxygen; $\mathrm{VHG}=$ vertical hydraulic gradient.

${ }^{*} p<.05$;

${ }^{* *} p<.01 ;$

${ }^{* * *} p<.001$.

\subsection{Faunal patterns}

A total of 100 taxa and 22,850 individuals were recorded from the 135 samples. Taxa most linked to the benthic habitat, that is, SX and TH, represented the main portion of the hyporheic assemblages of this river, with $68 \%$ of the taxa richness and $54 \%$ of the total abundance
(Table 3). The 12 most abundant taxa (accounting for $84.6 \%$ of the total) were Orthocladiinae ( $\mathrm{TH}, 18 \%)$, Oligochaeta ( $\mathrm{PH}, 14.7 \%)$, Leuctra cf. fusca (TH, 10.6\%), Baetis spp. (TH, 8.8\%), Diacyclops languidoides (SB, 7.9\%), Hydracarina ( $\mathrm{PH}, 5.3 \%)$, Caenis sp. ( $\mathrm{TH}, 4.1 \%)$, Proasellus walteri (SB, 3.9\%), Niphargopsis cf. casparyi (SB, 3.7\%), Niphargus sp. (SB, 3.5\%), Tanypodinae (TH, 2.3\%), and Phreatalona phreatica (SB, 1.8\%).

Overall differences in assemblages were observed between channels, depths, positions, and times (Table 4). No significant interactions were found among any channel-position-depth-time combinations (Table 4). except an interaction between channel and depth $(p=.0152)$. Nevertheless, interactions close to significance were found between channel $\times$ time $(p=.07)$, depth $\times$ time $(p=.05)$, and depth $\times$ position $\times$ time $(p=.07)$. Due to these between-channel differences, temporal changes were analysed separately in the two channels with a focus on temporal variations (Figures 4, 5). The NMDS1 reflected strong variation with depth, which was more marked in the impact channel (Figure 5b,d) than in the control channel (Figure 4b, d). The deepest depth (D3) was characterized by SB, such as the genera Proasellus, Niphargus, and Niphargopsis and the species Cryptocandona kieferi, Pseudocandona zschokkei, Acanthocyclops sensitivus, and P. phreatica (Figures 4a and 5a). The shallowest depth (D1) was associated with typical benthic fauna, such as most insect larvae and a few taxa of Crustacea (genera Gammarus and Asellus). Plotting sample NMDS coordinates per time did not reveal any temporal pattern in the control channel (Figure 4c), and two groups T1-T2 and T3-T4 were distinguished in the impact channel (Figure 5c). Temporal trajectories of change in assemblage composition were large and/or overlapped in the impact channel at D2 and D3 but were not related to the benthic fauna (variations in abundance of SB and $\mathrm{PH}$ species), whereas they did not overlap at D1 and were related to surface taxa (variations in abundance of SX and TH species), indicating differences between upstream and downstream positions at D1 (Figures $4 d$ and $5 d$ ).

TABLE 2 Mean (minimum-maximum) values of the six physicochemical parameters of water sampled in the control and impact channels at the two positions and the three depths

\begin{tabular}{|c|c|c|c|c|c|}
\hline & \multirow{2}{*}{$\begin{array}{l}\text { Channel } \\
\text { Position }\end{array}$} & \multicolumn{2}{|c|}{ Control } & \multicolumn{2}{|c|}{ Impact } \\
\hline & & Upstream & Downstream & Upstream & Downstream \\
\hline & Depth $(\mathrm{cm})$ & & & & \\
\hline $\mathrm{N}-\mathrm{NO}_{3}^{-}(\mathrm{mg} / \mathrm{L})$ & $\begin{array}{l}10 \\
50 \\
90\end{array}$ & $\begin{array}{l}0.63(0.51 ; 0.77) \\
0.62(0.50 ; 0.79) \\
0.64(0.51 ; 0.76)\end{array}$ & $\begin{array}{l}0.66(0.51 ; 0.76) \\
0.62(0.48 ; 0.71) \\
0.65(0.57 ; 0.88)\end{array}$ & $\begin{array}{l}0.61(0.52 ; 0.70) \\
0.64(0.40 ; 0.86) \\
0.65(0.49 ; 0.75)\end{array}$ & $\begin{array}{l}0.56(0.40 ; 0.77) \\
0.60(0.46 ; 0.74) \\
0.66(0.50 ; 0.78)\end{array}$ \\
\hline Specific conductance $(\mu \mathrm{S} / \mathrm{cm})$ & $\begin{array}{l}10 \\
50 \\
90\end{array}$ & $\begin{array}{l}359(349 ; 371) \\
355(344 ; 367) \\
357(348 ; 367)\end{array}$ & $\begin{array}{l}352(344 ; 361) \\
355(346 ; 364) \\
356(343 ; 365)\end{array}$ & $\begin{array}{l}356(338 ; 362) \\
354(340 ; 362) \\
357(344 ; 364)\end{array}$ & $\begin{array}{l}358(350 ; 365) \\
357(339 ; 365) \\
362(340 ; 381)\end{array}$ \\
\hline Temperature $\left({ }^{\circ} \mathrm{C}\right)$ & $\begin{array}{l}10 \\
50 \\
90\end{array}$ & $\begin{array}{l}21.3(19.1 ; 23.1) \\
21.2(19.2 ; 22.7) \\
20.8(19.1 ; 21.6)\end{array}$ & $\begin{array}{l}21.8(19.1 ; 23.3) \\
21.0(19.1 ; 22.4) \\
20.9(19.5 ; 21.8)\end{array}$ & $\begin{array}{l}22.0(20.2 ; 24.8) \\
21.3(19.7 ; 23.4) \\
21.0(19.7 ; 22.5)\end{array}$ & $\begin{array}{l}22.2(20.7 ; 24.5) \\
21.4(19.1 ; 23.1) \\
21.0(18.9 ; 23.0)\end{array}$ \\
\hline
\end{tabular}

Note. DO = dissolved oxygen; VHG = vertical hydraulic gradient. 
TABLE 3 Comparison of taxa collected in the control and impact channels: Presence-absence data (+) and ecological assignation of taxa represented in different colours to improve clarity

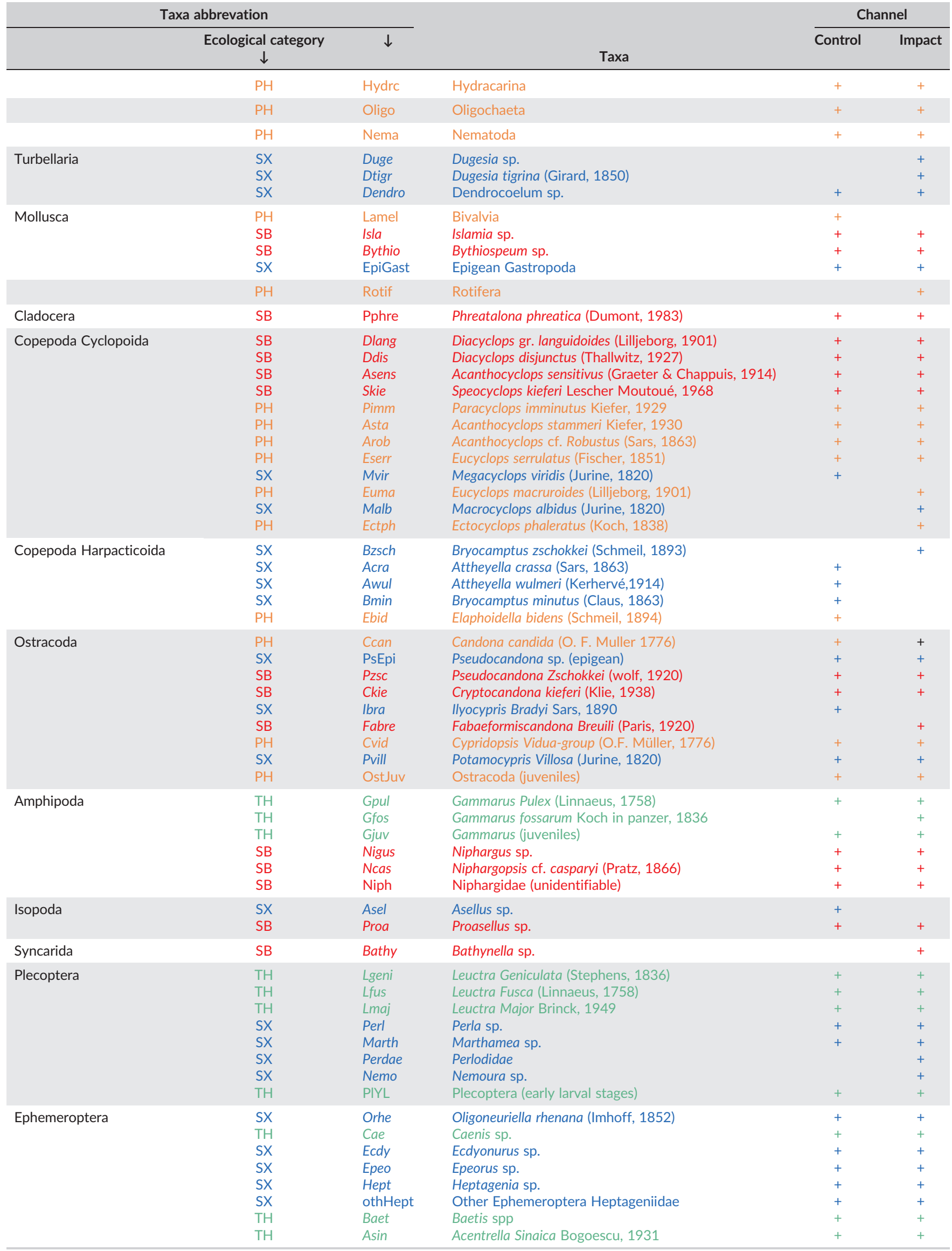




\begin{tabular}{|c|c|c|c|c|c|}
\hline \multicolumn{3}{|c|}{ Taxa abbrevation } & \multirow[b]{2}{*}{ Taxa } & \multicolumn{2}{|c|}{ Channel } \\
\hline & $\begin{array}{c}\text { Ecological category } \\
\downarrow\end{array}$ & $\downarrow$ & & Control & Impact \\
\hline & $\mathrm{TH}$ & Sign & Serratella Ignita (Poda, 1761) & & + \\
\hline & $\mathrm{TH}$ & Cpict & Choroterpes Picteti (Eaton, 1871) & + & + \\
\hline \multirow[t]{12}{*}{ Diptera } & SX & Simu & Simulidae & + & + \\
\hline & SX & Hexa & Hexatoma sp. & + & + \\
\hline & SX & Hexni & Hexatomini & + & + \\
\hline & SX & Taba & Tabanidae & + & + \\
\hline & $\mathrm{TH}$ & Cerat & Ceratopogonidae & + & + \\
\hline & $\mathrm{TH}$ & Ortnae & Orthocladiinae & + & + \\
\hline & $\mathrm{TH}$ & Tanp & Tanypodinae & + & + \\
\hline & $\mathrm{TH}$ & Tant & Tanytarsini & + & + \\
\hline & $\mathrm{TH}$ & Chiri & Chironomini & + & + \\
\hline & $\mathrm{TH}$ & Clino & Clinocerinae & + & + \\
\hline & $\mathrm{TH}$ & othEm & Other Empididae & & + \\
\hline & SX & Tipu & Tipulidae & & + \\
\hline \multirow[t]{11}{*}{ Coleoptera } & SX & ElmL & Elmis sp. (larva) & & + \\
\hline & $\mathrm{TH}$ & EsolL & Esolus sp. (larva) & + & + \\
\hline & $\mathrm{TH}$ & EsolA & Esolus sp. (adult) & + & + \\
\hline & SX & $\operatorname{LimL}$ & Limnius sp. (larva) & + & + \\
\hline & SX & $\operatorname{Lim} A$ & Limnius sp. (adult) & + & + \\
\hline & SX & OuliL & Oulimnius sp. (larva) & + & + \\
\hline & SX & LacA & Laccobius (adult) & + & + \\
\hline & SX & Yobi & Yola Bicarinata (Latreille, 1804) & & + \\
\hline & SB & Sieta & Siettitia Avenionensis Guignot, 1925 & & + \\
\hline & SX & Hydrop & Hydroporinae & + & + \\
\hline & SX & Dryo & Dryops sp. (adult) & + & \\
\hline \multirow[t]{12}{*}{ Trichoptera } & SX & Odalb & Odontocerum Albicorne (Scopoli, 1763) & & + \\
\hline & SX & Hinco & Hydropsyche Incognita Pitsch, 1993 & + & + \\
\hline & SX & Hexoc & Hydropsyche Exocellata Dufour, 1841 & + & + \\
\hline & SX & Hcont & Hydropsyche Contubernalis McLachlan, 1865 & & + \\
\hline & SX & Hydro & Hydropsyche spp. & + & + \\
\hline & SX & Clep & Cheumatopsyche Lepida (Pictet, 1834) & + & + \\
\hline & SX & Hydro & Hydroptila sp. & + & \\
\hline & SX & Cyrn & Cyrnus sp. & + & + \\
\hline & SX & othPol & Other Polycentropodidae & & + \\
\hline & SX & TrYL & Trichoptera (early larval stages) & + & + \\
\hline & SX & Cordu & Cordulegaster sp. & + & \\
\hline & SX & Micro & Micronecta sp. & & + \\
\hline
\end{tabular}

Note. $\mathrm{PH}=$ permanent hyporheos; $\mathrm{SB}=$ stygobite; $\mathrm{SX}=$ stygoxenes; $\mathrm{TH}=$ temporary hyporheos.

The temporal variation in the mean abundance of benthic taxa (SX and $\mathrm{TH}$ ), plotted by depth and by position, indicated no noticeable changes in the control channel, except at D3 (Figure 6a), where the observed sporadic changes were related to the nonbenthic fauna $(\mathrm{PH}$, SB). Similar temporal variations in the mean abundance of nonbenthic taxa were also apparent in the impact channel, whereas the greatest increase in the mean abundance of benthic taxa was observed at D1 and D2 at the upstream position (Figure 6b). The most contributive taxa to explain these changes were the Ephemeroptera Baetis sp. and Caenis sp., the Diptera Orthocladiinae and Tanypodinae, and the Plecoptera L. cf. fusca, for which the abundance increased at D1 and D2 into the HZ after 15 and $24 \mathrm{~h}$ of streambed drying (Appendix B.1). Nevertheless, the abundance of the most benthic taxa (SX), such as the Ephemeroptera Heptageniidae and Trichoptera, was low and did not vary significantly during the experiment.

\section{4 | DISCUSSION}

Although the consideration of nested hyporheic flowpaths is recognized as crucial for understanding hyporheic hydrology and the related physical processes (e.g., Dent, Grimm, \& Fisher, 2001; Poole et al., 2008), their effect on the biotic compartment (fishes, invertebrates, and microbes) remains poorly understood. The role of nested hyporheic flowpaths has been mainly demonstrated for fish reproduction and egg development (Baxter \& Hauer, 2000; Geist \& Dauble, 1998; Malcolm, Youngson, \& Soulsby, 2003; Saltveit \& Brabrand, 2013) and, more rarely, for the distribution of invertebrate assemblages (Capderrey et al., 2013; Creuzé des Châtelliers, 1991; Datry, Larned, \& Scarsbrook, 2007). The incorporation of such a complex hydrological framework into sampling designs is thus necessary to clarify issues deriving from the "HRH" and to predict the distribution of hyporheic refuges along rivers (Dole-Olivier, 2011). In the present study, in which local hyporheic flowpaths were nested in a large-scale downwelling, we observed slight but significant changes in water temperature, specific conductance, nitrate, and DO in the impact channel during drying (prediction 1 supported) indicating changes in hyporheic flow conditions. Concomitantly, the abundance of benthic taxa increased in the $\mathrm{HZ}$, whereas no change in invertebrate assemblages occurred in the control channel (prediction 2 supported). These changes were rapid, occurring after only 15 to $24 \mathrm{~h}$ of drying and were observed at the upstream but not the downstream position (prediction 3 supported). Invertebrate migrations were taxon-specific and were conducted by benthic taxa of the TH category. 
TABLE 4 Summary of permutational multivariate analysis of variance processed on the overall data set of fauna (control and impact channels) to test the influence of channel, position, depth, time, and their interactions

\begin{tabular}{|c|c|c|c|c|c|c|}
\hline & Df & SS & MS & $\mathbf{F}$ & $\mathrm{R}^{2}$ & $\mathrm{p}$ \\
\hline Channel (control vs. impact) & 1 & 0.8 & 0.8 & 4.12 & 0.024 & $.0002^{* * *}$ \\
\hline Position (upstream vs. downstream) & 1 & 0.54 & 0.54 & 2.79 & 0.016 & $.0048^{* *}$ \\
\hline Time (T1, T2, T3, and T4) & 3 & 1.04 & 0.35 & 1.78 & 0.031 & $.0093^{* *}$ \\
\hline Channel $\times$ position & 1 & 0.34 & 0.34 & 1.76 & 0.01 & .0602 \\
\hline Channel $\times$ time & 3 & 0.81 & 0.27 & 1.4 & 0.025 & .0771 \\
\hline Position $\times$ time & 3 & 0.48 & 0.16 & 0.83 & 0.015 & .7387 \\
\hline Depth $\times$ time & 6 & 0.55 & 0.26 & 1.33 & 0.047 & .0508 \\
\hline Channel $\times$ position $\times$ depth & 2 & 0.31 & 0.15 & 0.79 & 0.009 & .738 \\
\hline Channel $\times$ position $\times$ time & 3 & 0.75 & 0.25 & 1.3 & 0.023 & .1274 \\
\hline Residuals & 85 & 16.5 & 0.19 & & 0.499 & \\
\hline
\end{tabular}

$* p<.05$

${ }^{* *} p<.01$

${ }^{* * *} p<.001$.

\subsection{Temporal variations in hyporheic flowpaths (prediction 1)}

As predicted, the artificial drying altered the hydrological patterns in the impact channel. The increased frequency and amplitude of temperature variations due to changes in cloudiness during the period of intense solar radiation (08:00-19:00; Figure 2) was likely related to the lack of water at the sediment surface, which favoured heat conduction by the gravels. At the upstream position, these changes in hyporheic water temperature were visible deeper in the $\mathrm{HZ}$ compared to the downstream position. Deeper penetration of thermal oscillations below the head of riffles compared to the tail was also observed by Swanson and Cardenas (2010). As predicted, the significant temporal difference observed in the other abiotic parameters (Table 1, Figure 3 a,f,h) was mostly related to increasing values of nitrate (and to a lesser extent, specific conductance) and decreasing values of DO from T1 to T4, supporting our first prediction. This result, which was not observed in the control channel, may be interpreted as an increase in interstitial water drainage during drying due to the disappearance of surface water pressure. Nevertheless, this effect was limited due to the absence of connections with deep groundwater (Appendix A), and the range of variations was so small that water quality transformations cannot be invoked to explain faunal changes.

\subsection{Accumulation of benthic invertebrates in the $\mathrm{HZ}$ (prediction 2)}

Invertebrate assemblages varied with depth in both channels: SB were most abundant in deep zones (D3), and the benthic taxa (SX, TH) were mostly distributed in the top layer (D1, Figure 4a,b, Figure 5a,b). Variation with depth is a very common and dominant feature of the distribution and composition of the hyporheos (e.g., Danielopol, 1976; Dole \& Chessel, 1986; Dole-Olivier, Marmonier, \& Creuzé des Châtelliers, 1994; Gibbins, Grant, Malcolm, \& Soulsby, 2016; Mestrov \& Lattinger-Penko, 1981; Williams, 1984). In the present study, this effect was particularly strong. No significant temporal variations were observed in the control channel, indicating that the interstitial assemblages were stable during the experiment. This result demonstrated that the slight increase in discharge $\left(0.316 \mathrm{~m}^{3} / \mathrm{s}\right)$ in the control channel (total discharge $=3.574 \mathrm{~m}^{3} / \mathrm{s}$ ) due to flow diversion did not affect the hyporheic assemblages.

On the contrary, in the impact channel, our analyses highlighted differences between times ( $\mathrm{T} 1$ to $\mathrm{T} 4$ ) with more pronunced changes at T3 and T4, supporting our second prediction. As predicted, we observed an accumulation of organisms in the hyporheic sediments from T1 to T4 (e.g., a 6.7-fold increase in abundance at upstream position D1). From an ecological point of view, vertical migrations were conducted by some abundant, predominantly benthic taxa of the TH (Leuctra cf. fusca, Baetis sp., Caenis sp., Orthocladiinae, Tanypodinae Figure 5a), which were also the most abundant in the benthic assemblage of this river site (at predisturbance conditions; Dole-Olivier et al., 2014, Figure 4). Taxa belonging to the SX group did not migrate into the sediments, despite their reported dominance in the surface stream (e.g., Heptageniidae, Dole-Olivier et al., 2014). This result is in agreement with the ecological status of the taxa, as $\mathrm{TH}$ are regular residents of the $\mathrm{HZ}$ and spend part of their life cycle in the hyporheic interstices (Gibert et al., 1994), whereas SX are the most benthic taxa and typically live above the sediment surface (e.g., Perlodidae and Heptageniidae). Abundant TH taxa are thus more likely to migrate into the $\mathrm{HZ}$ than taxa strictly linked to surface flow and morphologically adapted to high current velocities. Animals requiring such velocities would not find conditions that are tolerable and able 
NMDS 2
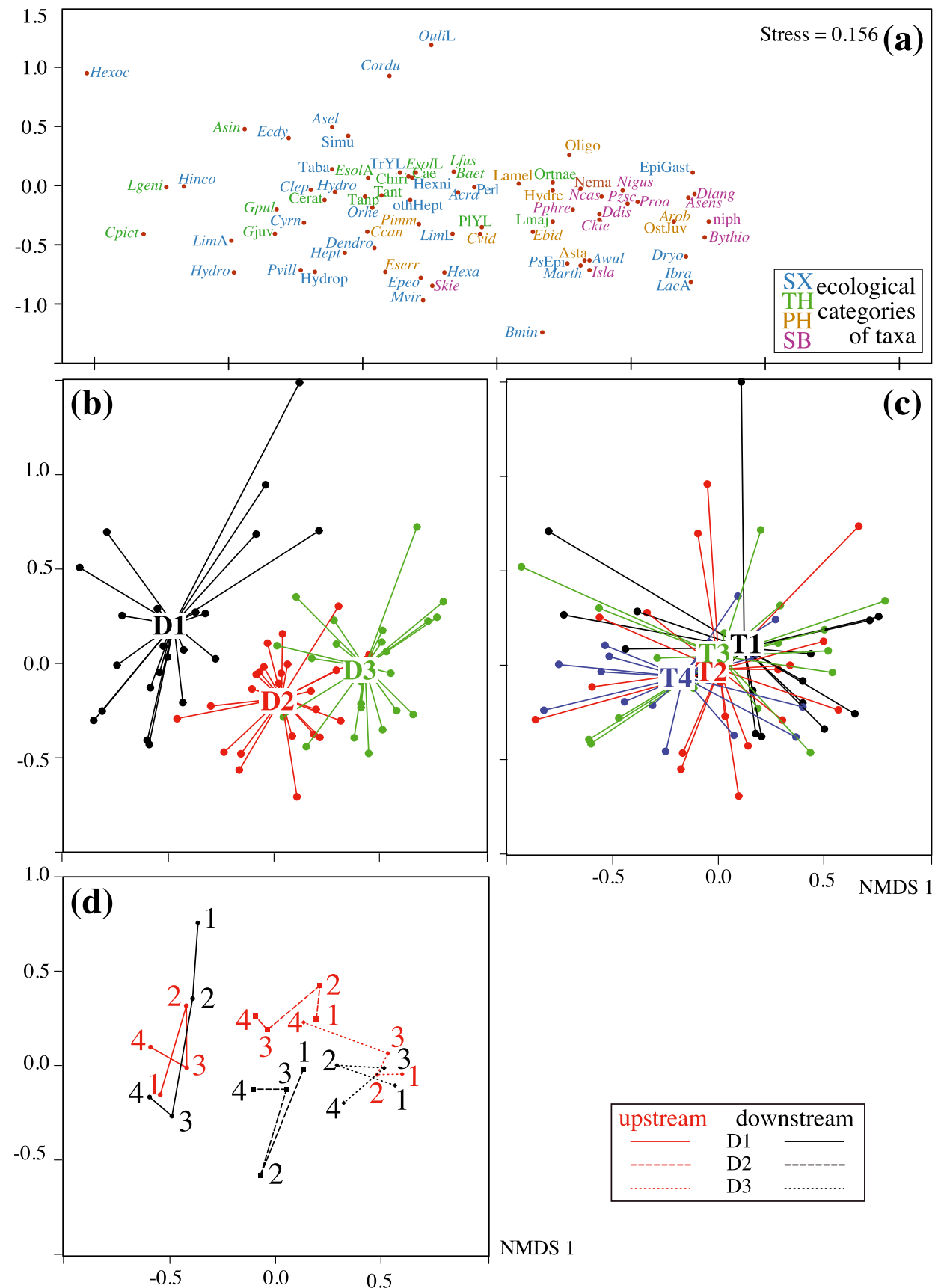

NMDS 1

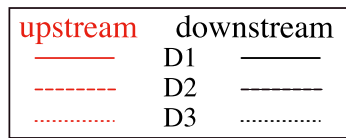

FIGURE 4 Nonmetric multidimensional scaling ordination plot of invertebrate abundance in the control channel. Taxa plotted according to their ecological categories (a); full taxonomic details of abbreviated genera are provided in Table 3; SX = stygoxenes, $\mathrm{TH}=$ temporary hyporheos, $\mathrm{PH}=$ permanent hyporheos, and SB = stygobites. Sample scores plotted according to depth (b) and time (c). Two-dimensional plot of sample centroids (three replicates) revealing the temporal trajectories of changes in invertebrate assemblages at the three depths and the two positions (d). Continuous, dashed, and dotted lines corresponds to depths D1, D2, and D3, respectively. Numbers 1 to 4 correspond to times T1 to T4

to promote persistence in the $\mathrm{HZ}$. In the $\mathrm{HZ}$ of both perennial and intermittent streams, Kelso (2012) reported increases in macroinvertebrate biomass in response to drying but no change in richness, suggesting that only specific taxa adapted to living in the interstices migrated into the $\mathrm{HZ}$.

This accumulation of benthic invertebrates was not immediate but occurred very quickly, between T2 and T3 (15 h). The most obvious changes were at depths D1 and D2, and no change was detectable at D3. It is unclear whether this observation was related to a low ability of the organisms to migrate deeper into the alluvia or to the short duration of the experiment. Studies reporting temporal changes during drying have generally recorded variations after longer sampling periods (several days, weeks, or months); for example, Clinton, Grimm, and Fisher (1996), Boulton and Stanley (1995), Del Rosario and Resh (2000), Fenoglio, Bo, Cucco, and Malacarne (2007), James, Dewson, and Death (2008a), and Vander Vorste, Malard, and Datry (2016). Studies such as the present one, reporting rapid migrations (between 1 and $2 \mathrm{~h}$ ) of benthic invertebrates into the $\mathrm{HZ}$, are still rare and mostly related to high-flow disturbance (Gayraud et al., 2000; Holomuzki \& Biggs, 2000). Nevertheless, Vadher et al. (2015) reported similar rapid 

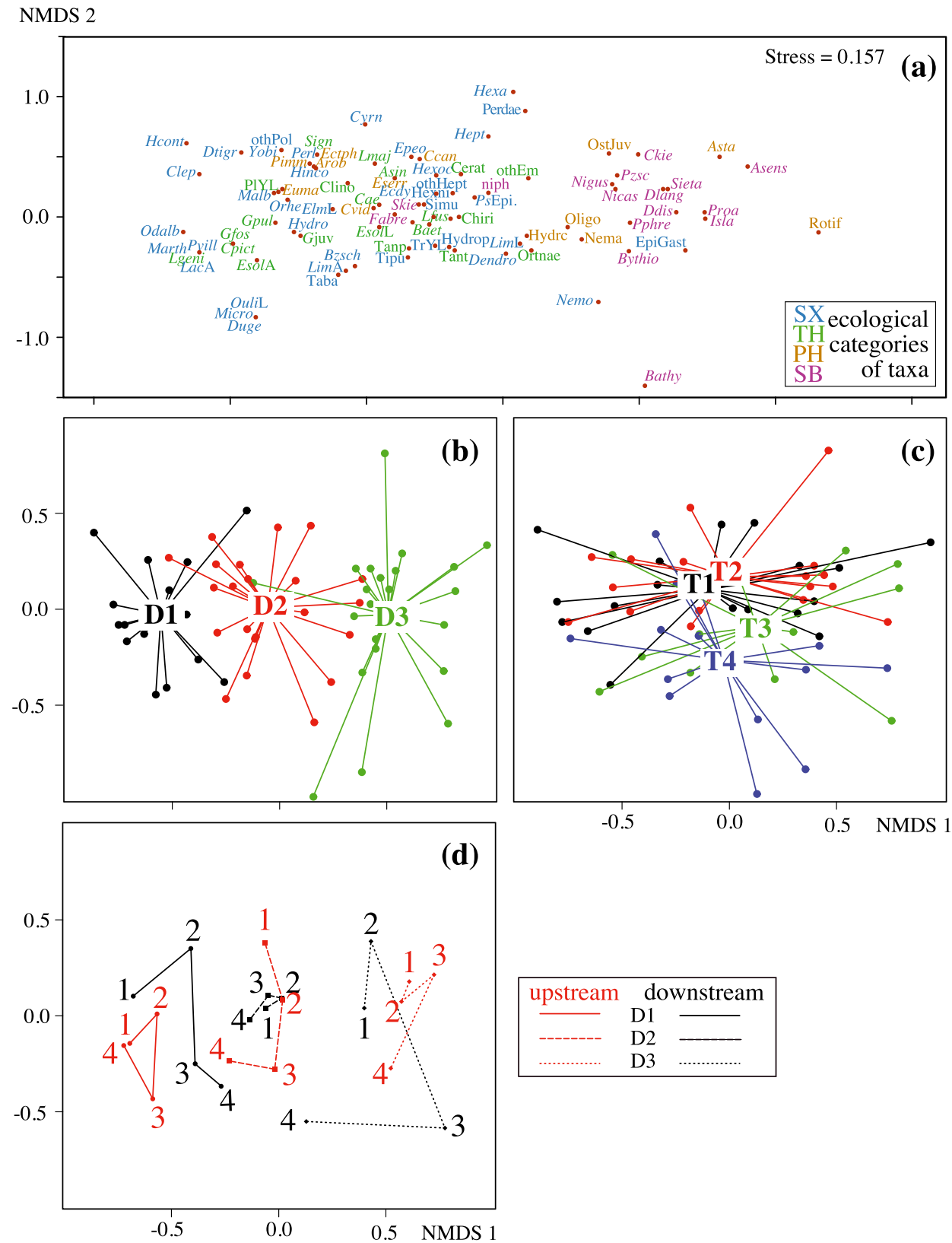

FIGURE 5 Nonmetric multidimensional scaling ordination plot of invertebrate abundance in the impact channel. (a) Plot of taxa represented by their ecological categories; full taxonomic details of abbreviated genera are provided in Table 3; SX $=$ stygoxenes, $\mathrm{TH}=$ temporary hyporheos, $\mathrm{PH}=$ permanent hyporheos, and SB = stygobites. Samples plotted according to depth (b) and time (c). Two-dimensional plot of sample centroids (three replicates) revealing the temporal trajectories of changes in invertebrate assemblages at the three depths and the two positions (d). Continuous, dashed, and dotted lines corresponds to depths D1, D2, and D3, respectively. Numbers 1 to 4 correspond to times T1 to T4

reactions ( $2 \mathrm{~h}$ ) when using surface water loss as an extreme stressor to trigger vertical migrations of Gammarus pulex into the HZ. Typically, aquatic organisms that lack adaptations to limit water loss (desiccation resistance) or the ability to escape desiccation by drift or flying must move very quickly into refuges to avoid perishing upon exposure to air. The most probable explanation for this fast reaction is that benthic organisms follow the water table into the $\mathrm{HZ}$ during drying to avoid desiccation. These organisms may also "sense" that river drying may occur soon because they may be sensitive to environmental changes (such as water depth, flow velocity, temperature, and DO), as is the case when they enter in drift during flow recession (James, Dewson,
\& Death, 2008b). Knowledge of the existence of such quick reactions is important to fully understand resilience processes in braided rivers because these systems are highly unstable and undergo very rapid disconnections of streamside channels, typically at low discharges when further, minimal discharge reductions in the main stream induces sudden disconnections of lateral channels. Recent laboratory studies have shown fast vertical migrations of invertebrates into the $\mathrm{HZ}$ (Vander Vorste, Mermillod-Blondin, et al., 2016), emphasizing not only the importance of vertical hydrologic exchanges but also their interactions with other factors, such as sedimentation and increased depth to the water table. 
(a) CONTROL channel

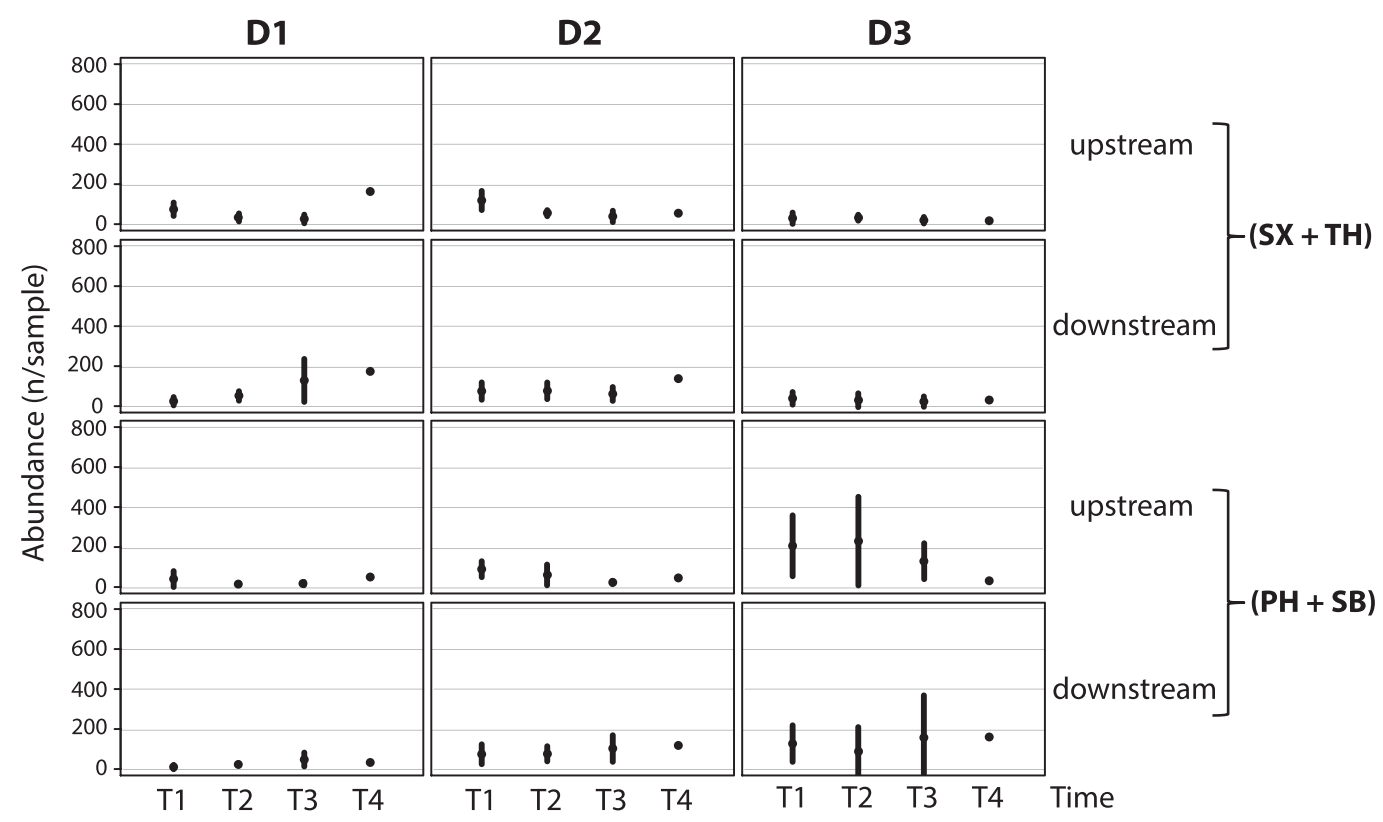

(b) IMPACT channel

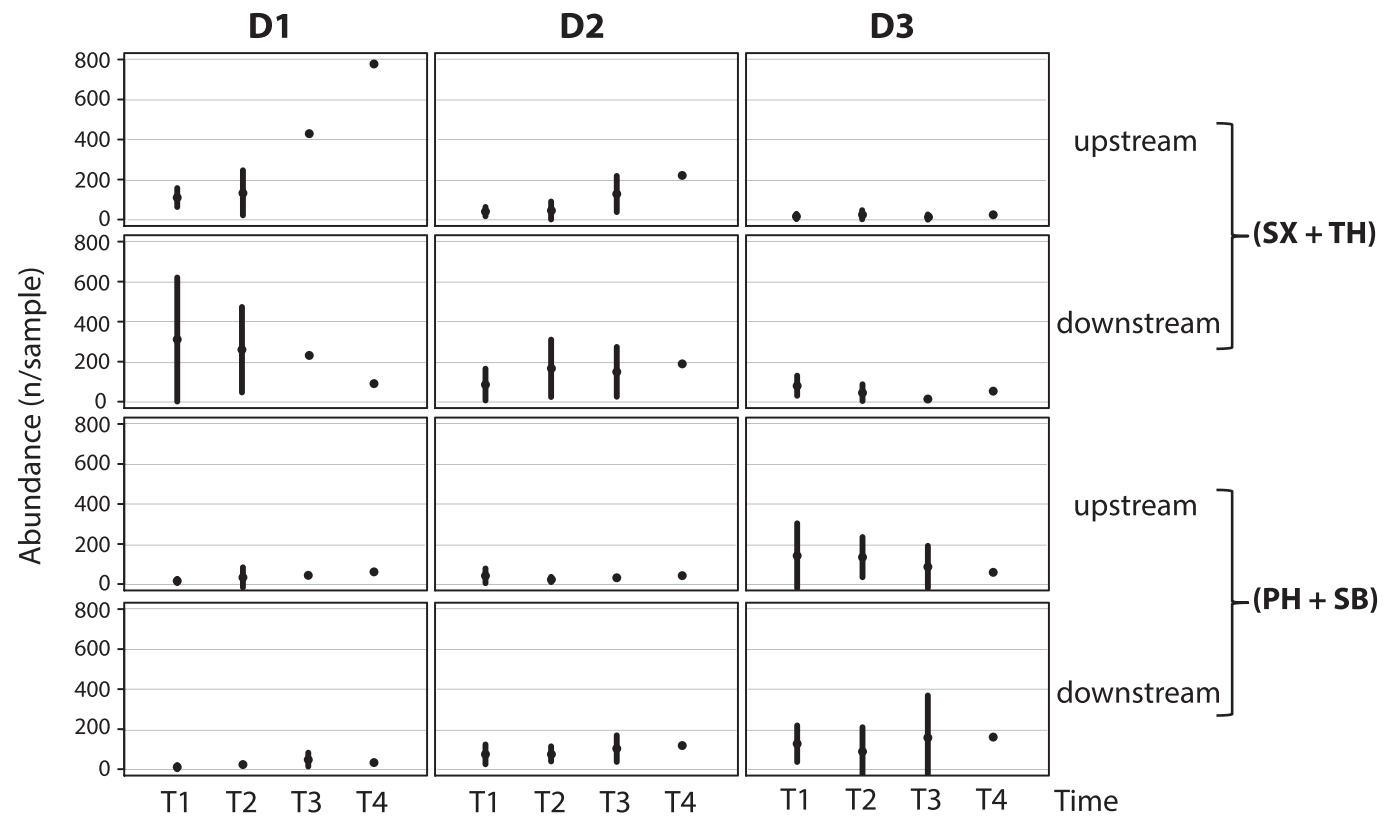

FIGURE 6 Mean abundance $( \pm \mathrm{SD})$ of benthic taxa $(\mathrm{SX}+\mathrm{TH})$ and nonbenthic taxa $(\mathrm{PH}+\mathrm{SB})$ in the control $(\mathrm{a})$ and impact $(\mathrm{b})$ channels at both upstream and downstream positions. Spatiotemporal variations from time T1 to time T4 at the three depths (D1, D2, and D3). SX = stygoxenes, $\mathrm{TH}=$ temporary hyporheos, $\mathrm{PH}=$ permanent hyporheos, and $\mathrm{SB}=$ stygobites

\section{3 | Hyporheic refuges and nested hyporheic flowpaths (prediction 3)}

Although many studies have reported the impacts of drying on benthic and hyporheic invertebrate communities (e.g., Boulton, 2003; Datry, 2012; James et al., 2008a; Stubbington, Wood, \& Boulton, 2009), few studies have examined disturbance-linked vertical migrations in relation to hyporheic flow patterns (Boulton \& Stanley, 1995; Kelso, 2012; Stubbington et al., 2011). As predicted, we observed differences in hyporheic migration between riffle positions, with the accumulation in the $\mathrm{HZ}$ occurring only upstream (downwelling zone). Thus, this local- scale downwelling nested in large-scale downwelling may represent a refuge zone, at least for some benthic taxa and for short study durations. As suggested by some authors, the hydrological situation of downwelling is susceptible to promoting refuge use (Kelso, 2012). On the contrary, at the downstream position (upwelling zone), invertebrate abundance did not vary in the $\mathrm{HZ}$ during drying. In two karst rivers in the UK, Stubbington et al. (2011) observed an increase in hyporheic abundance of Gammarus pulex and total invertebrate abundance during low-flow conditions, specifying that the hyporheic refuge use was more pronounced at sites where downwelling of surface water dominated (which may be interpreted as a major 
downwelling). They proposed that the direction of water movement potentially facilitated downward migrations and that the influence of water quality (mainly DO and temperature) on hyporheic water chemistry increased the suitability of the hydrological environment for benthic taxa. In contrast, in areas where upwelling dominated, James et al. (2008a) found the vertical distribution of hyporheic macroinvertebrates unaltered by a 1-month period of flow reduction because the increasing influence of cooler groundwater inflows maintained favourable conditions in the surface stream. It is also possible that flow recession is not a strong enough stressor to trigger invertebrate migrations in the $\mathrm{HZ}$.

These findings demonstrate the possible contrasting influences of large-scale hyporheic exchanges of water on hyporheic refuges, although it is not always possible to determine whether water exchanges occur at riffle or floodplain scales. On the other hand, some study-cases illustrating the influence of hyporheic flow paths on benthic invertebrate migrations during hydrological disturbances are available at a local scale (Boulton \& Stanley, 1995; Dole-Olivier et al., 1997). However, to our knowledge, examples mixing both scales, that is, studying the influence of nested hyporheic exchanges, are extremely rare and only related to the selection of spawning habitat by salmonids and to the growth, development, and survival of eggs and fry. These studies demonstrated that organisms were clearly sensitive to two distinct spatial scales, as the best conditions were found in local downwellings nested in large-scale upwelling areas (e.g., Baxter $\&$ Hauer, 2000). These areas may combine thermal stability due to the major upwelling with oxygen availability due to the local-scale downwelling. The authors emphasized that, without a hierarchical approach to the interaction between hyporheic exchange and bull trout spawning, they would have obtained an erroneous picture of spawning habitat selection. The development of such a hierarchical approach is probably crucial for understanding not only fish spawning and development in the $\mathrm{HZ}$ but also hyporheic migrations of invertebrates during critical periods. Because the accumulation of organisms in bed sediments during a disturbance is not sufficient to demonstrate that the $\mathrm{HZ}$ is a true refuge (and not, for example, a graveyard), it is also necessary to measure the efficiency of subsequent recolonization from these HZ refuges (Kawanishi, Inoue, Dohi, Fujii, \& Miyake, 2013; Vander Vorste, Malard, et al., 2016; Vander Vorste, Mermillod-Blondin, et al., 2016).

\section{5 | CONCLUSION}

Hydrological and biological changes were observed a short time after the beginning of streambed drying $(<15 \mathrm{~h})$. The abundance of dominant taxa increased in the first strata of the bed sediments (D1 and D2), indicating that some benthic organisms had migrated into the HZ. Considering both scales, this case study demonstrates that the $\mathrm{HZ}$ may act as a refuge for the dominant $\mathrm{TH}$ benthic taxa during drying when local downwellings are nested in a major downwelling.

In situ, manipulations are essential to test results from laboratory experiments, especially into the $\mathrm{HZ}$ where experiments remain challenging. In this respect, the present field study combines original features, as it was the first attempt to test the hyporheic refuge in nested hyporheic flowpaths and used an artificial manipulation of flow at the streamside channel scale. Experiments were also conducted in braided rivers, recognized for their great physical instability and their predisposition to dry at low discharges. The acquisition of data in such rivers is associated with a high degree of risk of possible sudden variations in discharge during the study course. The counterpart of these originalities is the impossibility of replicating the design under the same conditions. Considering that this study represents one piece of a large puzzle, there is clearly a need for complementary case studies conducted within a range of hydrogeological frameworks (Dole-Olivier, 2011). For example, a test of the hyporheic refuge in local flowpaths nested in a large-scale upwelling would be particularly promising to complete the framework used in other studies lacking nested scales (e.g., James et al., 2008a). Large-scale upwelling should ensure water permanency in the $\mathrm{HZ}$ during drying, stable temperatures, and high sediment permeability, wherein local-scale downwelling should ensure the availability of resources, such as organic matter and oxygen (Dole-Olivier, 2011).

Such a hydrological approach, based on the recognition of nested hyporheic flowpaths from geology and the form of the valley and from streambed forms, is crucial to predict the distribution of hyporheic refuges and the location of hyporheic biodiversity hotspots along the river course. With climate change, the frequency of critical hydrological periods and river drying is predicted to increase in some regions. Considering also that water resource pressures interact with climatic changes to influence flow permanence, deep knowledge about hyporheic refuges-their locations and their efficiency for recolonization-will be essential to improve river management and to maintain biodiversity and good ecological functioning of streams. Thus, we recommend that water managers take greater interest in the knowledge and protection of such important refuges (Storey \& Quinn, 2013).

\section{ACKNOWLEDGEMENTS}

This work was supported by the InBioProcess project (ANR-06-BDIV007-InBioProcess 2007-2010) of the Biodiversity 2006 program of the French National Research Agency (ANR). We thank the two referees for their careful review of the manuscript. We also thank Pr. P. Usseglio-Polatera (University of Lorraine, Metz) for his statistical advice, the Natural Reserve of the "Ramières du Val de Drôme" for granting access to sampling sites; L. Pattard, S. Segura, and J. Vallès for their contribution in sorting invertebrates. Many colleagues and friends have helped to achieve the fieldwork (C. Colson-Proch, S. Doledec, C. Dubuis, D. Eme, M. Forcellini, L. Houriez, N. Houriez, F. Malard., S. Merigoux, F. Mermillod-Blondin, S. Navel, A. Nguyen, C. Piscart, F. Proch, M. Poli, and D. Reynaud). We also thank Pr. D. Culver (American University, Washington) for improving the English style of this manuscript and for providing its scientific advice.

\section{REFERENCES}

Angelier, E. (1953). Recherches écologiques et biogéographiques sur la faune des sables submergés. Archives de Zoologie Expérimentale et Générale, 90, 37-162. 
Baxter, C. V., \& Hauer, F. R. (2000). Geomorphology, hyporheic exchange, and selection of spawning habitat by bull trout (Salvelinus Confluentus). Canadian Journal of Fisheries and Aquatic Sciences, 57, 1470-1481. https://doi.org/10.1139/f00-056

Baxter, C., Hauer, F. R., \& Woessner, W. W. (2003). Measuring groundwater-stream water exchange: New techniques for installing minipiezometers and estimating hydraulic conductivity. Transactions of the American Fisheries Society, 132, 493-502. https://doi.org/ 10.1577/1548-8659(2003)132<0493:MGWENT > 2.0.CO;2

Bou, C., \& Rouch, R. (1967). Un nouveau champ de recherches sur la faune aquatique souterraine. Comptes Rendus de l'Académie des Sciences, 265, 369-370.

Boulton, A. J. (2003). Parallels and contrasts in the effects of drought on stream macroinvertebrate assemblages. Freshwater Biology, 48, 1173-1185. https://doi.org/10.1046/j.1365-2427.2003.01084.x

Boulton, A., Datry, T., Kasahara, T., Mutz, M., \& Stanford, J. (2010). Ecology and management of the hyporheic zone: Stream-groundwater interactions of running waters and their floodplains. Journal of the North American Benthological Society, 29, 26-40. https://doi.org/10.1899/ 08-017.1

Boulton, A. J., Dole-Olivier, M.-J., \& Marmonier, P. (2003). Optimizing a sampling strategy for assessing hyporheic invertebrate biodiversity using the Bou-Rouch method: Within site replication and sample volume. Archiv für Hydrobiologie, 156, 431-456. https://doi.org/10.1127/ 0003-9136/2003/0156-0431

Boulton, A. J., Dole-Olivier, M.-J., \& Marmonier, P. (2004). Effects of sample volume and taxonomic resolution on assessment of hyporheic assemblage composition sampled using a Bou-Rouch pump. Archiv für Hydrobiologie, 159, 327-355. https://doi.org/10.1127/0003-9136/ 2004/0159-0327

Boulton, A. J., Harvey, M. S., \& Proctor, H. (2004). Of spates and species: Responses by interstitial water mites to simulated spates in a subtropical Australian river. Experimental and Applied Acarology, 34, 149-169. https://doi.org/10.1023/B:APPA.0000044445.30246.b2

Boulton, A. J., \& Stanley, E. H. (1995). Hyporheic processes during flooding and drying in a Sonoran desert stream. II. Faunal dynamics. Archiv für Hydrobiologie, 134, 27-52.

Bretschko, G. (1992). The sedimentfauna in the uppermost parts of the impoundment "Altenwörth" (Danube, stream km 2005 and 2007). Archiv für Hydrobiologie, 84, 131-168.

Brunke, M., \& Gonser, T. (1997). The ecological significance of exchange processes between rivers and groundwater. Freshwater Biology, 37, 1-33. https://doi.org/10.1046/j.1365-2427.1997.00143.x

Buffington, J. M., \& Tonina, D. (2009). Hyporheic exchange in mountain rivers II: Effects of channel morphology on mechanics, scales and rates of exchange. Geography Compass, 3, 1038-1062. https://doi.org/ 10.1111/j.1749-8198.2009.00225.x

Capderrey, C., Datry, T., Claret, C., \& Malard, F. (2013). Invertebrate distribution across nested geomorphic features in braided-river landscapes. Freshwater Science, 32, 1188-1204. https://doi.org/10.1899/12-188.1

Clinton, S. M., Grimm, N. B., \& Fisher, S. G. (1996). Response of a hyporheic invertebrate assemblage to drying disturbance in a desert stream. Journal of the North American Benthological Society, 15, 700-712. https:// doi.org/10.2307/1467817

Creuzé des Châtelliers, M. (1991). Geomorphological processes and discontinuities in the macrodistribution of the interstitial fauna. A working hypothesis. Verhandlungen der Internationalen Vereinigung fuer theoretische und angewandte Limnologie, 24, 1609-1612.

Dahm, C. N., \& Valett, H. M. (1996). Hyporheic zones. In Methods in stream ecology. New York: Academic Press.

Dai, A. (2011). Drought under global warming: A review. WIREs Climatic Change, 2, 45-65. https://doi.org/10.1002/wcc.81

Danielopol, D. L. (1976). The distribution of the fauna in the interstitial habitats of riverine sediments of the Danube and the Piesting (Austria). International Journal of Speleology, 8, 23-51. https://doi.org/10.5038/ 1827-806X.8.1.3
Datry, T. (2012). Benthic and hyporheic invertebrate assemblages along a flow intermittence gradient: Effects of duration of dry events. Freshwater Biology, 57, 563-574. https://doi.org/10.1111/j.13652427.2011.02725.x

Datry, T., Larned, S. T., \& Scarsbrook, M. R. (2007). Responses of hyporheic invertebrate assemblages to large-scale variation in flow permanence and surface-subsurface exchange. Freshwater Biology, 52, 1452-1462. https://doi.org/10.1111/j.1365-2427.2007.01775.x

Datry, T., Malard, F., \& Gibert, J. (2005). Response of invertebrate assemblages to increased groundwater recharge rates in a phreatic aquifer Journal of the North American Benthological Society, 24, 461-477. https://doi.org/10.1899/04-140.1

del Rosario, R. B., \& Resh, V. H. (2000). Invertebrates in intermittent and perennial streams: Is the hyporheic zone a refuge from drying? Journal of the North American Benthological Society, 19, 680-696. https://doi. org $/ 10.2307 / 1468126$

Dent, C. L., Grimm, N. B., \& Fisher, S. G. (2001). Multiscale effects of surface-subsurface exchange on stream water nutrient concentrations. Journal of the North American Benthological Society, 20, 162-181. https://doi.org/10.2307/1468313

Dole, M.-J., \& Chessel, D. (1986). Stabilité physique et biologique des milieux interstitiels. Cas de deux stations du Haut Rhône. Annales de Limnologie, 22, 69-81. https://doi.org/10.1051/limn/1986008

Dole-Olivier, M.-J. (1998). Surface water/groundwater exchanges in three dimensions on a backwater of the Rhône river. Freshwater Biology, 40, 93-109. https://doi.org/10.1046/j.1365-2427.1998.00335.x

Dole-Olivier, M.-J. (2011). The hyporheic refuge hypothesis reconsidered: A review of hydrological aspects. Marine Freshwater Research, 62, 1281-1302. https://doi.org/10.1071/MF11084

Dole-Olivier, M.-J., Maazouzi, C., Cellot, B., Fiers, F., Galassi, D. M. P., Claret, C., ... Marmonier, P. (2014). Assessing invertebrate assemblages in the subsurface zone of stream sediments (0-15 cm deep) using a hyporheic sampler. Water Resources Research, 50, 453-465. https:// doi.org/10.1002/2012WR013207

Dole-Olivier, M.-J., \& Marmonier, P. (1992a). Effects of spates on interstitial assemblages structure. Disturbance-perturbation relationship, rate of recovery. Hydrobiologia, 230, 49-61. https://doi.org/10.1007/ BF00015114

Dole-Olivier, M.-J., \& Marmonier, P. (1992b). Patch distribution of interstitial communities: Prevailing factors. Freshwater Biology, 27, 177-191. https://doi.org/10.1111/j.1365-2427.1992.tb00532.x

Dole-Olivier, M.-J., Marmonier, P., \& Beffy, J.-L. (1997). Response of invertebrates to lotic disturbance: Is the hyporheic zone a patchy refugium? Freshwater Biology, 37, 257-276. https://doi.org/10.1046/j.13652427.1997.00140.x

Dole-Olivier, M.-J., Marmonier, P., \& Creuzé des Châtelliers, M. (1994). Interstitial systems: Case studies -10.1--the alluvial plains of the Rhône River, France. In J. Gibert, D. L. Danielopol, \& J. A. Stanford (Eds.), Groundwater Ecology (pp. 313-346). San Diego, California: Academic Press.

Dray, S., \& Dufour, A. B. (2007). The ade4 package: Implementing the duality diagram for ecologists. Journal of Statistical Software, 22, 1-20. https://doi.org/10.18637/jss.v022.i04

Fenoglio, S., Bo, T., Cucco, M., \& Malacarne, G. (2007). Response of benthic invertebrate assemblages to varying drought conditions in the Po river (NW Italy). Italian Journal of Zoology, 74, 191-201. https://doi.org/ 10.1080/11250000701286696

Gayraud, S., Philippe, M., \& Maridet, L. (2000). The response of benthic macroinvertebrates to artificial disturbance: Drift or vertical movement in the gravel bed of two sub-Alpine streams? Archiv fur Hydrobiologie, 147, 431-446. https://doi.org/10.1127/archiv-hydrobiol/147/2000/ 431

Geist, D. R., \& Dauble, D. D. (1998). Redd site selection and spawning habitat use by fall Chinook salmon: The importance of geomorphic features in large rivers. Environmental Management, 22, 655-669. https://doi. org/10.1007/s002679900137 
Gibbins, C. N., Grant, J., Malcolm, I. A., \& Soulsby, C. (2016). Influence of groundwater chemistry on hyporheic invertebrate asemblages is revealed by fine-scale sampling. Fundamental and Applied Limnology, 187, 207-221. https://doi.org/10.1127/fal/2016/0787

Gibert, J., Stanford, J. A., Dole-Olivier, M.-J., \& Ward, J. V. (1994). Basic attributes of groundwater ecosystems and prospects for research. In J. Gibert, D. L. Danielopol, \& J. A. Stanford (Eds.), Groundwater ecology (pp. 7-40). San Diego, California: Academic Press.

Grashoff, K., Ehrhardt, M., \& Kremling, K. (1983). Methods of seawater analysis (2nd ed.). Berlin: Verlag Chemie.

Gunderson, L. H. (2000). Ecological resilience-in theory and application. Annual Review of Ecology and Systematics, 31, 425-439. https://doi. org/10.1146/annurev.ecolsys.31.1.425

Hendricks, S. P. (1993). Microbial ecology of the hyporheic zone: A perspective integrating hydrology and biology. Journal of the North American Benthological Society, 12, 70-78. https://doi.org/10.2307/ 1467687

Holomuzki, J. R., \& Biggs, B. J. (2000). Taxon-specific responses to highflow disturbance in streams: Implications for population persistence. Journal of the North American Benthological Society, 19, 670-679. https://doi.org/10.2307/1468125

Idees-Eaux. (2011). Suivi de l'influence d'un prélèvement dans la Drôme et sa nappe d'accompagnement --Simulations par modélisation mathématique. Report BB-110315-EHY.

James, A. B. W., Dewson, Z. S., \& Death, R. G. (2008a). Do stream macroinvertebrates use instream refugia in response to severe short-term flow reduction in New Zealand streams? Freshwater Biology, 53, 1316-1334. https://doi.org/10.1111/j.1365-2427.2008.01969.x

James, A. B. W., Dewson, Z. S., \& Death, R. G. (2008b). The effect of experimental flow reductions on macroinvertebrate drift in natural and streamside channels. River Research and Applications, 24, 22-35. https://doi.org/10.1002/rra.1052

Kawanishi, R., Inoue, M., Dohi, R., Fujii, A., \& Miyake, Y. (2013). The role of the hyporheic zone for a benthic fish in an intermittent river: A refuge, not a graveyard. Aquatic Sciences, 75, 425. https://doi.org/10.1007/ s00027-013-0289-4

Kelso, J. (2012). Macroinvertebrate communities and their use of refuge in intermittent and perennial streams. M.S., University of Central Arkansas, 1-99.

Lake, P. S. (2003). Ecological effects of perturbation by drought in flowing waters. Freshwater Biology, 48, 1161-1172. https://doi.org/10.1046/ j.1365-2427.2003.01086.x

Lancaster, J., \& Belyea, L. R. (1997). Nested hierarchies and scaledependence of mechanisms of flow refugium use. Journal of the North American Benthological Society, 16, 221-238. https://doi.org/ $10.2307 / 1468253$

Lehner, B., Döll, P., Alcamo, J., Henrichs, T., \& Kaspar, F. (2006). Estimating the impact of global change on flood and drought risks in Europe: A continental integrated analysis. Climatic Change, 75, 273-299. https:// doi.org/10.1007/s10584-006-6338-4

Malard, F., Ferreira, D., Dolédec, S., \& Ward, J. V. (2003). Influence of groundwater upwelling on the distribution of the hyporheos in a headwater river flood plain. Archiv für Hydrobiologie, 157, 89-116. https:// doi.org/10.1127/0003-9136/2003/0157-0089

Malard, F., Tockner, K., Dole-Olivier, M.-J., \& Ward, J. V. (2002). A landscape perspective of surface-subsurface hydrological exchanges in river corridors. Freshwater Biology, 47, 621-640. https://doi.org/ 10.1046/j.1365-2427.2002.00906.x

Malard, F., Tockner, K., \& Ward, J. V. (1999). Shifting dominance of subcatchment water sources and flow paths in a glacial floodplain, Val Roseg, Switzerland. Artic, Antartic, and Alpine Research, 31, 135-150. https://doi.org/10.2307/1552602

Malard, F., Ward, J. V., \& Robinson, C. T. (2000). An expanded perspective of the hyporheic zone. Verhandlungen der Internationalen Vereinigung für Theoretische und Angewandte Limnologie, 27, 431-437.
Malcolm, I. A., Youngson, A. F., \& Soulsby, C. (2003). Survival of salmonid eggs in a degraded gravel-bed stream: Effects of groundwater-surface water interactions. River Research and Applications, 19, 303-316. https://doi.org/10.1002/rra.706

Marmonier, P., \& Creuzé des Châtelliers, M. (1991). Effects of spates on interstitial assemblages of the upper Rhône River. Importance of spatial heterogeneity. Hydrobiologia, 210, 243-251. https://doi.org/10.1007/ BF00034683

Marmonier, P., \& Dole, M.-J. (1986). Les Amphipodes des sédiments d'un bras court-circuité du Rhône : logique de répartition et réaction aux crues. Sciences de l'eau, 5, 461-486.

Mestrov, M., \& Lattinger-Penko, R. (1981). Investigation of the mutual influence between a polluted river and its hyporheic. International Journal of Speleology, 11, 159-171 Available at: https://doi.org/10.5038/ 1827-806X.11.1.15

Oksanen, J., Blanchet, F. G., Kindt, R., Legendre, P., Minchin, P. R., O'Hara, R. B., ... Wagner, H. (2012). Vegan: Community ecology package, R package version 2.0-3. http://CRAN.R-project.org/package=vegan

Palmer, M. A., Bely, A. E., \& Berg, K. E. (1992). Response of invertebrates to lotic disturbance: A test of the hyporheic refuge hypothesis. Oecologia, 89, 182-194.

Poole, G. C., O'Daniel, S. J., Jones, K. L., Woessner, W. W., Bernhardt, E. S., Helton, A. M., ... Beechie, T. J. (2008). Hydrologic spiralling: The role of multiple interactive flow paths in stream ecosystems. River Research and Applications, 24, 1018-1031. https://doi.org/10.1002/rra.1099

Poole, G. C., Stanford, J. A., Running, S. W., \& Frissel, C. A. (2006). Multiscale geomorphic drivers of groundwater flow paths: Subsurface hydrologic dynamics and hyporheic habitat diversity. Journal of the North American Benthological Society, 25, 288-303. https://doi.org/ 10.1899/0887-3593(2006)25[288:MGDOGF]2.0.CO;2

R Development Core Team. (2011). R: A language and environment for statistical computing. R Foundation for Statistical Computing, Vienna, Austria. ISBN 3-900051-07-0, URL http://www.R-project.org/

Rolls, R. J., Leigh, C., \& Sheldon, F. (2012). Mechanistic effects of low-flow hydrology on riverine ecosystems: Ecological principles and consequences of alteration. Freshwater Science, 31, 1163-1186. https://doi. org/10.1899/12-002.1

Rouch, R. (1995). Peuplement des Crustacés dans la zone hyporhéique d'un ruisseau des Pyrénées. Annales de Limnologie, 31, 9-28. https://doi.org/ 10.1051/limn/1995006

Saltveit, S. J., \& Brabrand, Å. (2013). Incubation, hatching and survival of eggs of Atlantic salmon (Salmo Salar) in spawning redds influenced by groundwater. Limnologica, 43, 325-331. Available at: https://doi.org/ 10.1016/j.limno.2013.05.009

Sherman, K. M., \& Coull, B. C. (1980). The response of meiofauna to sediment disturbance. Journal of Impact Marine Biology and Ecology, 46, 59-71 https://doi.org/DOI: 10.1016/0022-0981(80)90091-X

SOGREHA. (1991). Etude diagnostic de la basse vallée de la Drôme. Direction départementale de l'équipement de la Drôme.

Storey, R. G., \& Quinn, J. M. (2013). Survival of aquatic invertebrates in dry bed sediments of intermittent streams: Temperature tolerances and implications for riparian management. Freshwater Science, 32, 250-266. https://doi.org/10.1899/12-008.1

Strayer, D. L., May, S. E., Nielsen, P., Wollheim, W., \& Hausam, S. (1997). Oxygen, organic matter, and sediment granulometry as controls on hyporheic animal communities. Archiv für Hydrobiologie, 140, 131-144. https://doi.org/10.1127/archiv-hydrobiol/140/1997/131

Stubbington, R. (2012). The hyporheic zone as an invertebrate refuge: A review of variability in space, time, taxa and behaviour. Marine and Freshwater Research, 63, 293-311. Available at: https://doi.org/ 10.1071/MF11196

Stubbington, R., Hoggan, J.-P., \& Wood, P. J. (2017). Characterization of the density and body size of a Gammarus pulex (Crustacea: Amphipoda) population in subsurface sediments reflects the sampling technique used. Hydrobiologia, 788, 293-303. https://doi.org/10.1007/s10750016-3008-z 
Stubbington, R., Wood, P. J., \& Boulton, A. J. (2009). Low flow controls on benthic and hyporheic macroinvertebrate assemblages during supraseasonal drought. Hydrological Processes, 23, 2252-2263. https://doi. org/10.1002/hyp.7290

Stubbington, R., Wood, P. J., Reid, I., \& Gunn, J. (2011). Benthic and hyporheic invertebrate community responses to seasonal flow recession in a groundwater-dominated stream. Ecohydrology, 4, 500-511. https://doi.org/10.1002/eco.168

Swanson, T. E., \& Cardenas, M. B. (2010). Diel heat transport within the hyporheic zone of a pool-riffle-pool sequence of a losing stream and evaluation of models for fluid flux estimation using heat. Limnology and Oceanography, 55, 1741-1754. https://doi.org/10.4319/ 10.2010.55.4.1741

Tockner, K., Malard, F., Burgherr, P., Robinson, C. T., Uehlinger, U., Zah, R., \& Ward, J. V. (1997). Physico-chemical characterization of channel types in a glacial floodplain ecosystem (Val Roseg, Switzerland). Archiv für Hydrobiologie, 140, 433-463. https://doi.org/10.1127/archivhydrobiol/140/1997/433

Tonina, D., \& Buffington, J. M. (2007). Hyporheic exchange in gravel bed rivers with pool-riffle morphology: Laboratory experiments and threedimensional modelling. Water Resources Research, 43, W01421. https://doi.org/10.1029/2005WR004328

Vadher, A. N., Stubbington, R., \& Wood, P. J. (2015). Fine sediment reduces vertical migrations of Gammarus Pulex (Crustacea: Amphipoda) in response to surface water loss. Hydrobiologia, 753, 61-71. https://doi. org/10.1007/s10750-015-2193-5

Vander Vorste, R., Malard, F., \& Datry, T. (2016). Is drift the primary process promoting the resilience of river invertebrate communities? A manipulative field experiment in an intermittent alluvial river. Freshwater Biology, 61, 1276-1292. https://doi.org/10.1111/fwb.12658
Vander Vorste, R., Mermillod-Blondin, F., Hervant, F., Mons, R., Forcellini, M., \& Datry, T. (2016). Increased depth to the water table during river drying decreases the resilience of Gammarus pulex an alters ecosystem function. Ecohydrology, 9, 1177-1186. https://doi.org/10.1002/ eco.1716

Venables, W. N., \& Ripley, B. D. (2002). Modern applied statistics with S (4th ed.). New York: Springer. ISBN: 0-387-95457-0.

Wentworth, C. K. (1922). A scale of grade and class terms for clastic sediments. The Journal of Geology, 30, 377-392. https://doi.org/10.1086/ 622910

White, D. S. (1993). Perspectives on defining and delineating hyporheic zones. Journal of the North American Benthological Society, 12, 61-69. https://doi.org/10.2307/1467686

Williams, D. D. (1984). The hyporheic zone as a habitat for aquatic insects and associated arthropods. In V. H. Resh, \& D. M. Rosenberg (Eds.), The ecology of aquatic insects (pp. 430-455). New York: Praeger Publishers.

Woessner, W. W. (2000). Stream and fluvial plain ground water interactions: Rescaling hydrogeologic thought. Ground Water, 38, 423-429. https://doi.org/10.1111/j.1745-6584.2000.tb00228.x

\section{APPENDIX A}

\section{Nested hyporheic flowpaths inferred from physicochemical data}

The hydrological investigation consisted of the description of the nested hyporheic flowpaths at the riffle scale ("local" down- and upwelling, Hendricks, 1993) and at the floodplain scale ("major" downor upwelling, Malard et al., 2000; Capderrey et al., 2013). The use of physicochemical indicators of water exchanges (Capderrey et al., 2013; Gibbins et al., 2016) allowed a consistent description of the hyporheic flowpaths in the river segment. Compared to surface water, cooler temperatures in summer, high specific conductance, low DO, high VHG, and $\mathrm{N}^{-\mathrm{NO}_{3}}{ }^{-}$are typical characteristics of groundwater (Hendricks, 1993; Dole-Olivier \& Marmonier, 1992b; Brunke \& Gonser, 1997; Tockner et al., 1997).

\section{Temperature}

In the control channel at depth D1, diurnal variations in temperature were similar at upstream and downstream positions (min-max: 18.4-23.7 ${ }^{\circ} \mathrm{C}$, Figure 2a), with decreasing amplitude and increasing delay (7-12 h) from D1 to D4. Nevertheless, although variations at D2 were close to those observed at D3 at the upstream riffle position, they were intermediate between those observed at D1 and at D3-D4 at the downstream position. Thus, the upstream position reflected poor exchanges between D1 and the other depths, whereas the similarity of curves from the intermediate depths (D2 and D3) suggested greater connections between these layers, with the deepest one (D4) being the most stable over time. At the downstream position, exchanges were more important between D1 and D2, indicating slow infiltration of surface water until D2; the D3 and D4 depths were more stable and closely connected. Finally, temperature patterns in the control channel indicated surface water infiltration at both positions, with more pronounced infiltration downstream.

In the impact channel at depth D1, diurnal variations were also similar at both positions (min-max: $18.4-24.3^{\circ} \mathrm{C}$ ), with decreasing amplitude and increasing delay from D1 to D4 and extremely low temporal variation at D4 ( $\min -\max : 19-19.9^{\circ} \mathrm{C}$ ). Although the temperature variations at D2 were very similar to those observed at D1 at the upstream position, they were more similar to those recorded at D3 at the downstream position. Thus, at the upstream position, the proximity of D1 and D2 curves reflected the infiltration of surface water until D2. At the downstream site, poor exchanges were observed between D1 and the other depths, whereas the similarity of curves from the intermediate depths (D2 and D3) indicated great connections between these layers, with the deepest one (D4) being more stable than in the control channel. Finally, temperature patterns in the impact channel reflected a downwelling at the upstream position and a weak upwelling at the downstream position (Swanson \& Cardenas, 
2010). In both positions, this effect was limited in depth and amplitude, indicating the presence of subsurface flowpaths (also called "domain of bedform-scale exchange flows" by Capderrey et al., 2013).

Generally, the low amplitude of spatial variation in water temperature along with minima close to $18{ }^{\circ} \mathrm{C}$ (i.e., rather high values) indicated no connections with deep phreatic waters, which are typically much cooler in this area (e.g., $13.3^{\circ} \mathrm{C}$ on $04 / 06 / 2009$, Dole-Olivier, unpublished data) arguing for the absence of large-scale upwelling (also called "domain of valley segment-scale exchange flows" by Capderrey et al., 2013).

\section{Other parameters}

No differences between the control and impact channels were observed for the five other parameters (specific conductance, DO, $\mathrm{N}-\mathrm{NO}_{3}{ }^{-}, \mathrm{VHG}$, and $\mathrm{Cl}^{-}$), whereas the upstream and downstream positions were significantly different (Table 1). The significant interaction between channel and position indicated that betweenposition differences were not similar in the two channels. In the impact channel, differences between samples collected upstream and downstream appeared along the PC1-PC2 axes $(54.42 \%$ of the total variability, Figure 3e), and samples from both positions were not separated in the control channel (Figure 3c). These variations in the impact channel were mostly linked to higher specific conductance and VHG as well as lower water oxygenation at the downstream position compared to the upstream position (Figure 3a). Nevertheless, the differences between surface and interstitial water were very weak, and the amplitude of vertical changes in the parameters (Table 2) was minimal compared to other studies in which hyporheic water upwelled mixed with deep groundwater (e.g., the amplitude of vertical change between surface and hyporheic water may reach $\sim 200$ and $\sim 400 \mu \mathrm{S} / \mathrm{cm}$ of specific conductance in two different water bodies of the Rhône River system; Dole-Olivier, 1998; Dole-Olivier et al., 1997).

\section{Nested hyporheic flowpaths}

These results demonstrated that riffle-scale hyporheic flowpaths were poorly marked in the studied area. Moreover, earlier data from the same sector of the river revealed strong differences in water quality between surface water and the deep aquifer. For example, specific conductance may reach $320-326 \mu \mathrm{S} / \mathrm{cm}$ in the surface flow, for $372-488 \mu \mathrm{S} / \mathrm{cm}$ and $447-657 \mu \mathrm{S} / \mathrm{cm}$ in the deep alluvia of the two sides of the floodplain (Idees-Eaux, 2011). Furthermore, measurements performed during the study period in a deep well adjacent to the floodplain (depth $>4 \mathrm{~m}$ ) indicated conductivities $>600 \mu \mathrm{S} / \mathrm{cm}(04 / 06 / 2009$, Dole-Olivier, unpublished data) for an average value of $357 \mu \mathrm{S} / \mathrm{cm}$ (min-max: $338-381 \mu \mathrm{S} / \mathrm{cm}$ ) in the $\mathrm{HZ}$. Corroborating the temperature data, the low range of variation and the low maxima in specific conductance values in the $\mathrm{HZ}(381 \mu \mathrm{S} / \mathrm{cm})$ indicated the absence of connections with deep phreatic waters. As local-scale patterns were not contrasted and the values of physicochemical indicators in the $\mathrm{HZ}$ were close to those measured in the surface stream, we conclude that local hyporheic flowpaths were nested in a large-scale downwelling. The local patterns are summarized in Figure $2 \mathrm{~b}$.

\section{Remark}

Contrary to most reports in the literature (Brunke \& Gonser, 1997; Buffington \& Tonina, 2009), the large-scale downwelling in the present work was situated at the end of the floodplain. This situation is unusual and could be linked to the artificial morphology of the valley. Under natural conditions, the constriction of a floodplain also corresponds to underground geological constraints (such as bedrock outcrops or valley narrowing) that create natural obstacles and oblige groundwater to upwell (Buffington \& Tonina, 2009; Capderrey et al., 2013; Malard et al., 2000; Poole et al., 2006). Here, the physical barrier closing the floodplain was an embankment narrowing the river along $4.5 \mathrm{~km}$ (Figure 1), and it seems that this artificial channelization acted as a physical constraint for the surface flow but not as a nickpoint for the aquifer. To our knowledge, no studies have considered nested hyporheic exchanges within artificially constrained river segments. Supplementing the hydrogeological description of the studied river section, this case reveals that the surface morphology of a stream that is artificially transformed by embankment is no longer a reliable indicator of large-scale surface water or groundwater exchanges. 


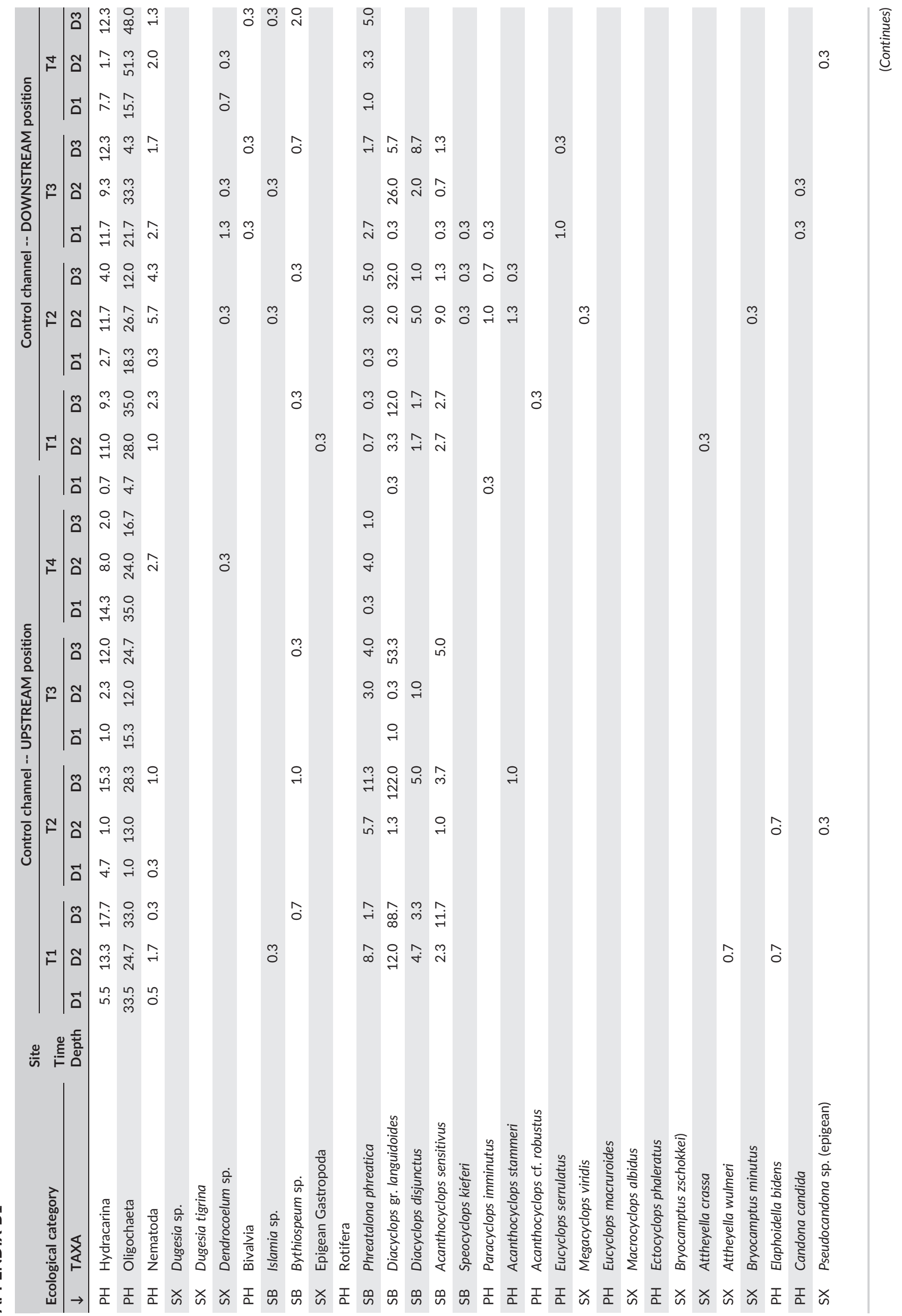




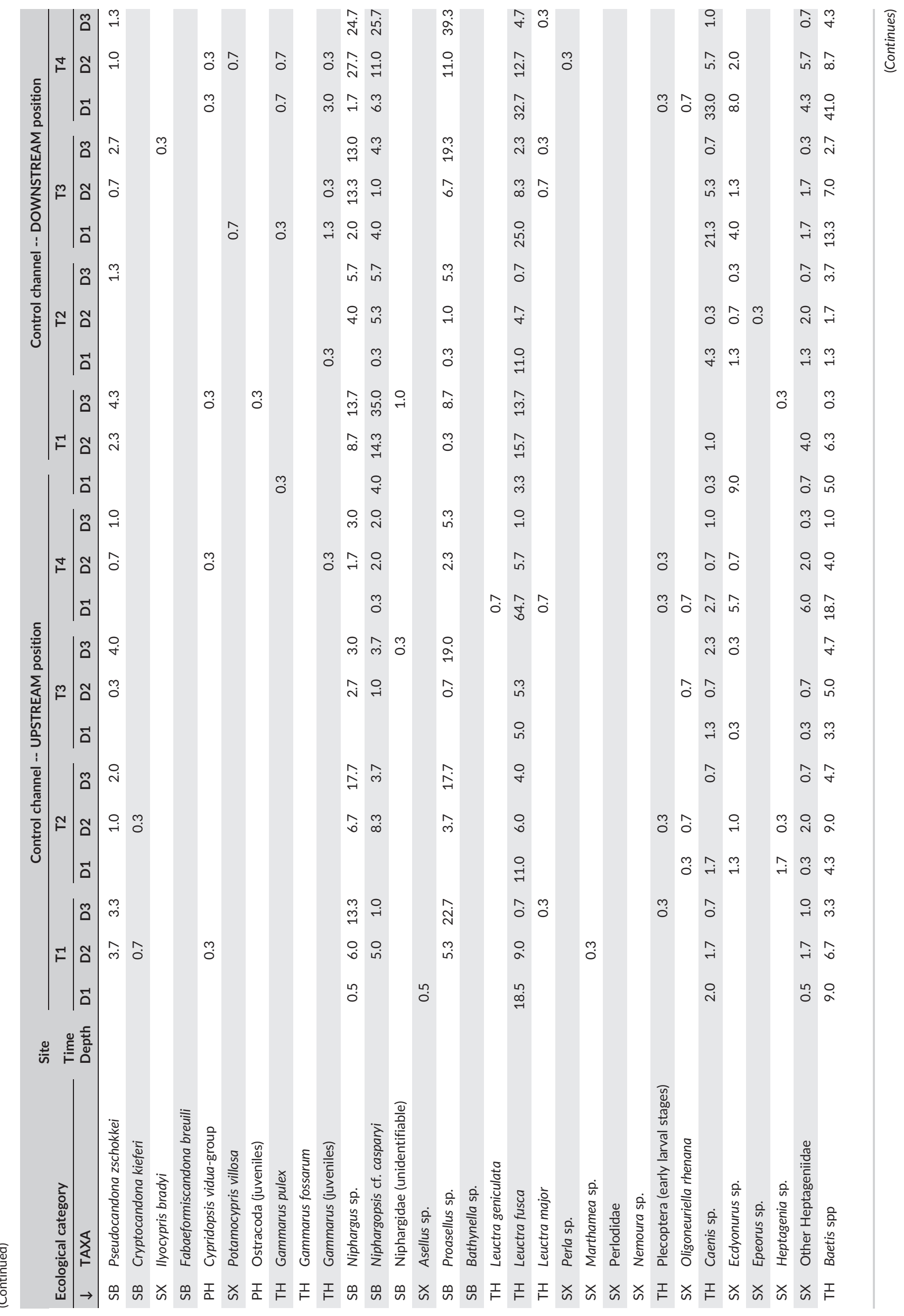




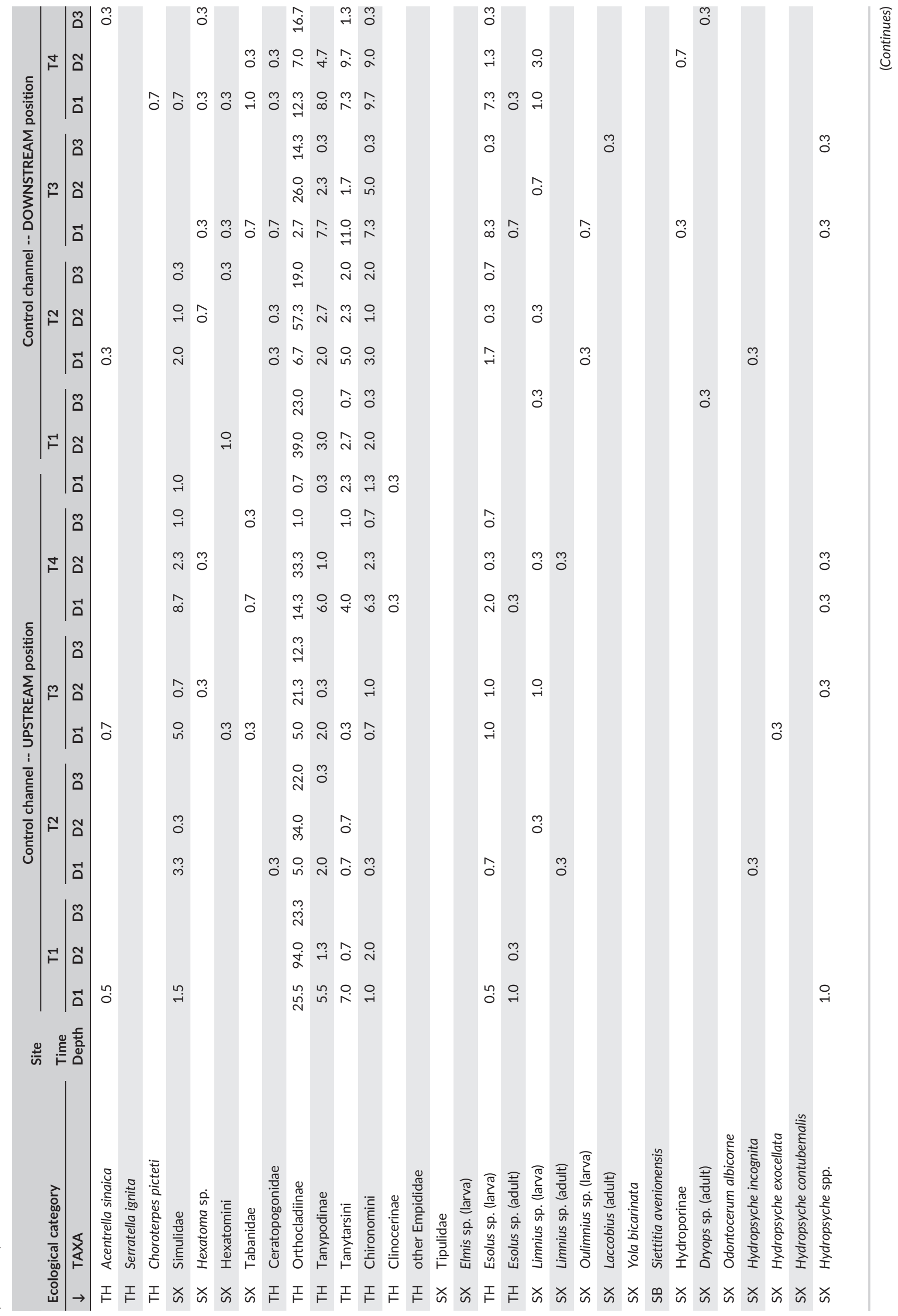




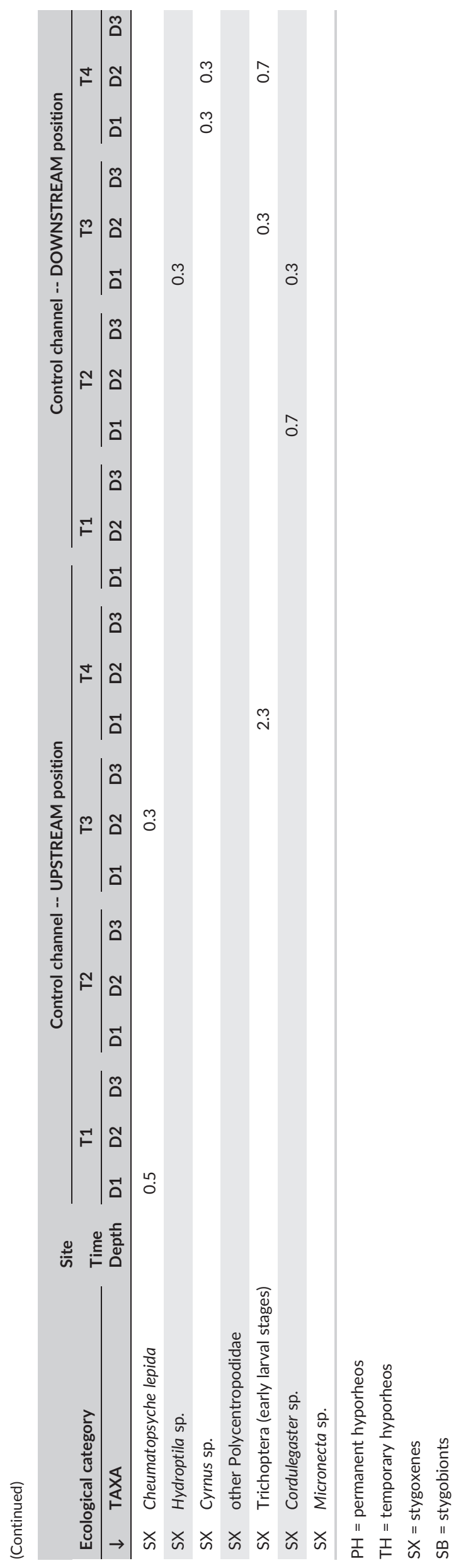




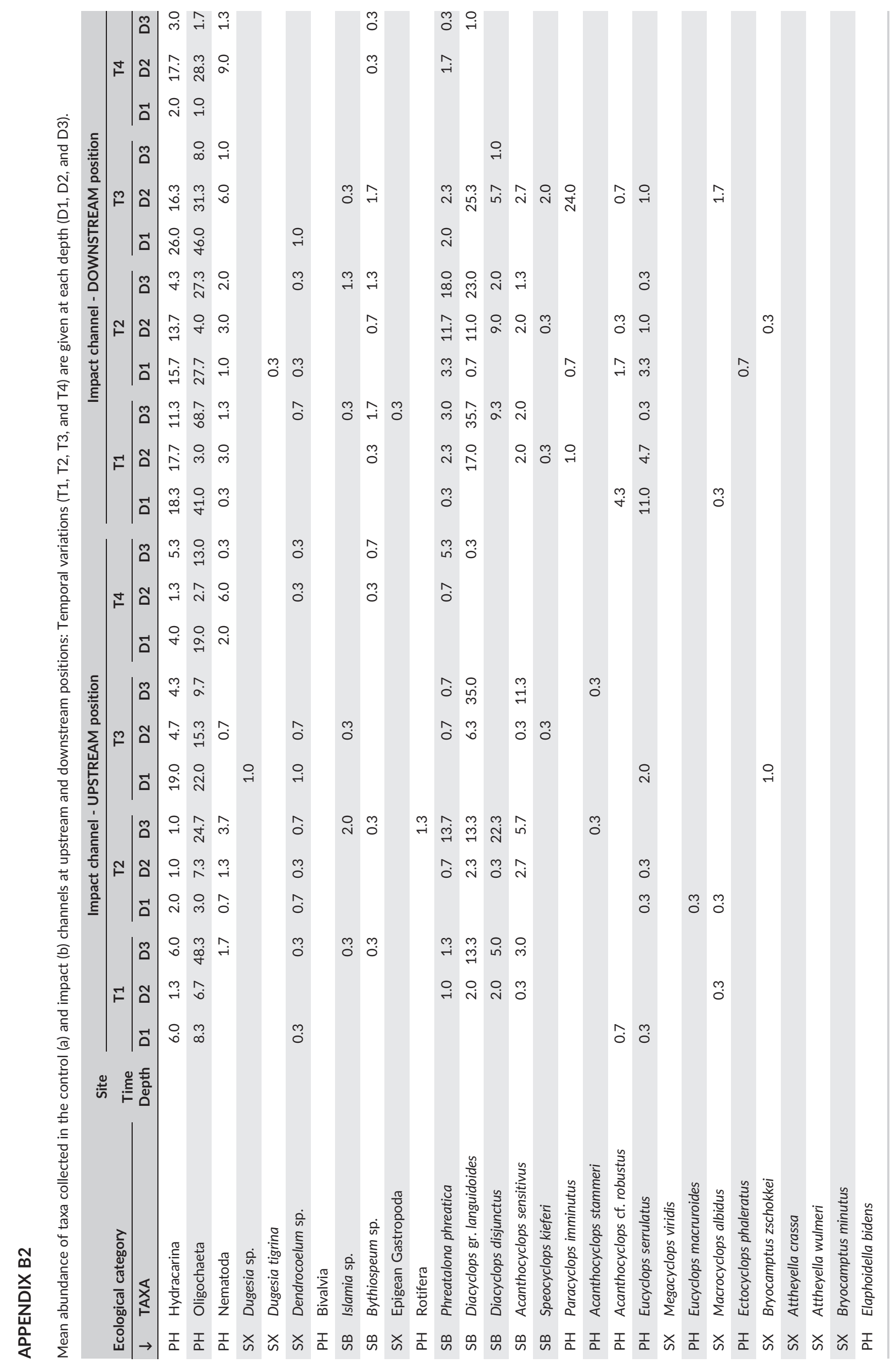




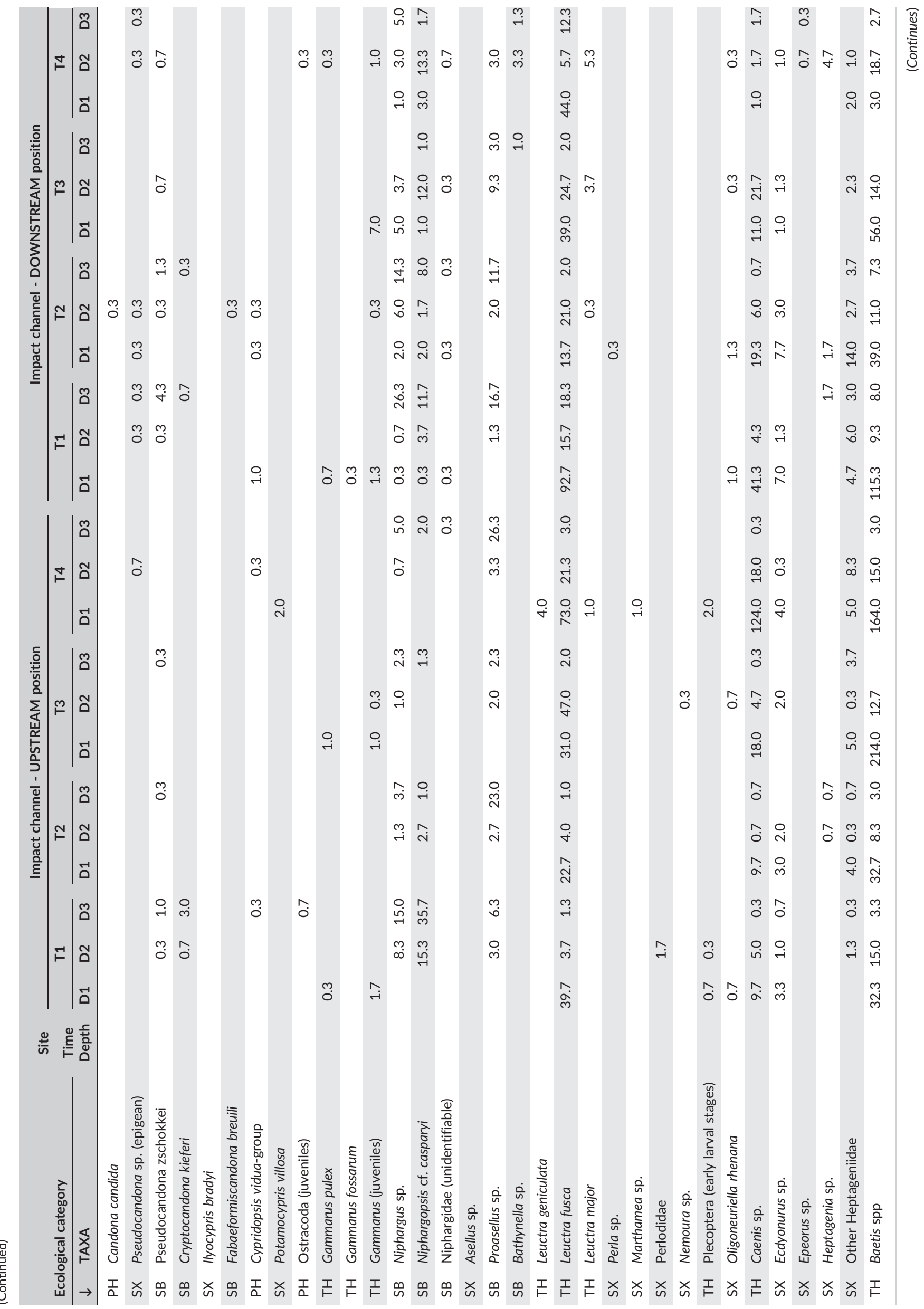




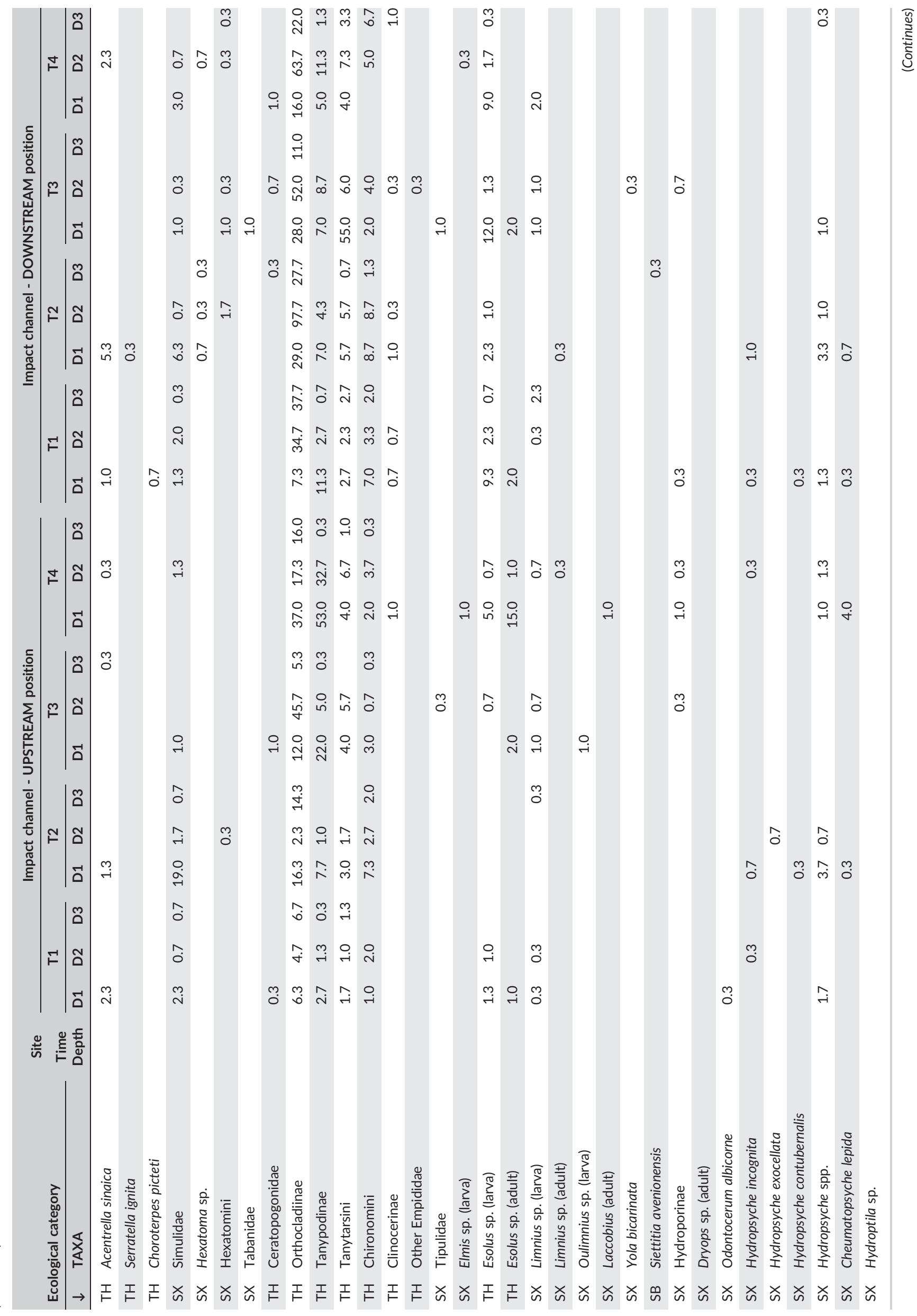




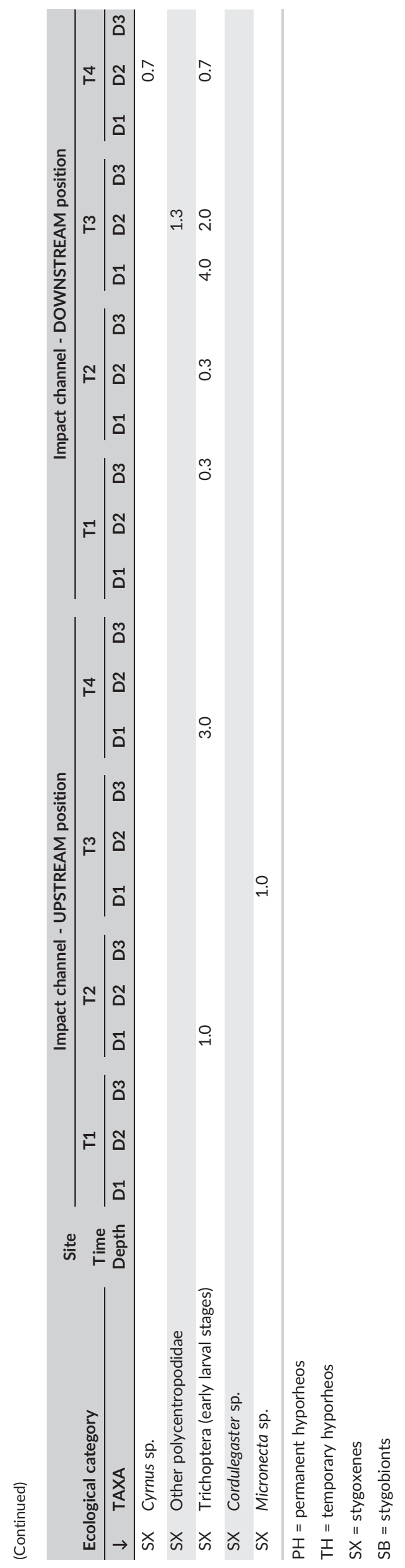

